Portland State University

PDXScholar

$11-22-1982$

\title{
Burt Brown Barker: His Role in Historic Preservation in Oregon
}

Mark Fredric Peterson

Portland State University

Follow this and additional works at: https://pdxscholar.library.pdx.edu/open_access_etds

Part of the Historic Preservation and Conservation Commons, and the History Commons Let us know how access to this document benefits you.

\section{Recommended Citation}

Peterson, Mark Fredric, "Burt Brown Barker: His Role in Historic Preservation in Oregon" (1982). Dissertations and Theses. Paper 3416.

https://doi.org/10.15760/etd.5295

This Thesis is brought to you for free and open access. It has been accepted for inclusion in Dissertations and Theses by an authorized administrator of PDXScholar. Please contact us if we can make this document more accessible: pdxscholar@pdx.edu. 
AN ABSTRACT OF THE THESIS OF Mark Fredric Peterson for the Master of Arts in History presented November 22, 1982.

Title: Burt Brown Barker, His Role in Historic: Preservation in Oregon.

APPROVED BY MEMBERS OF THE THESIS COMMITTEE,

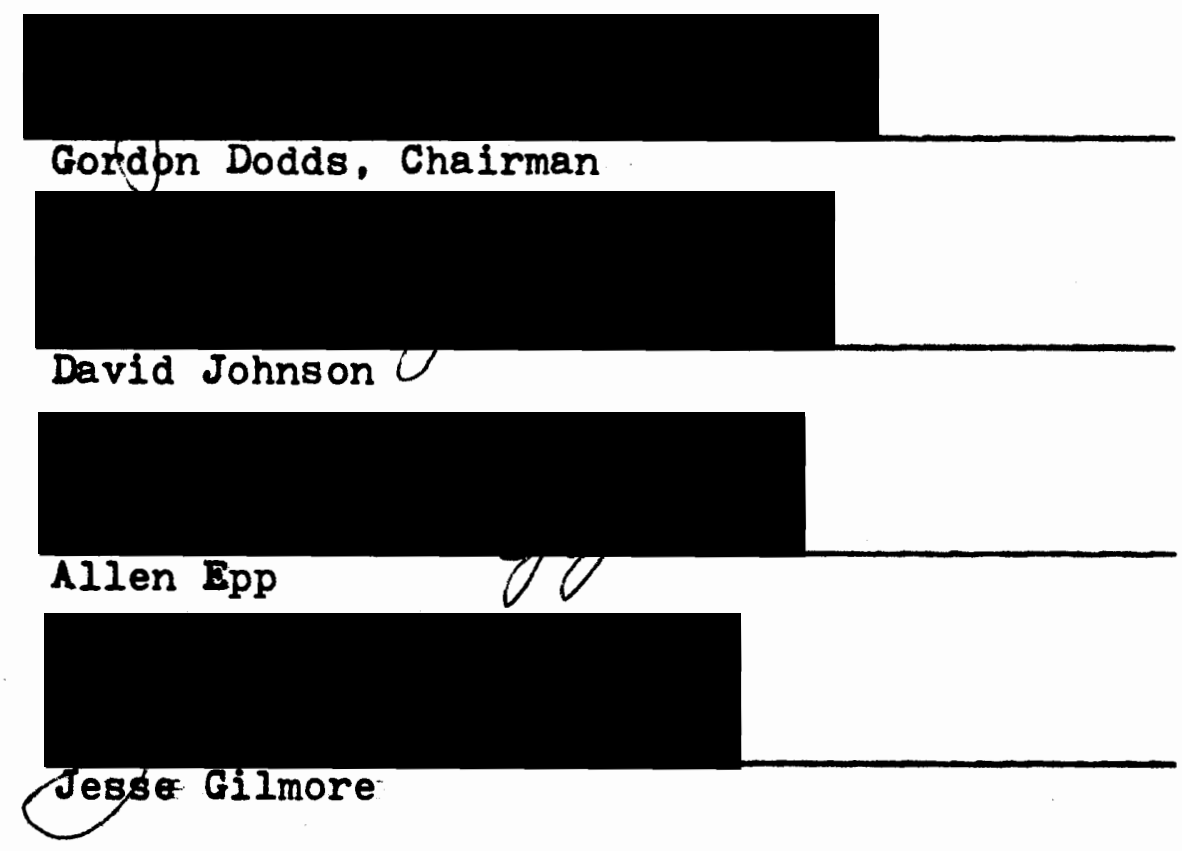

The field of historic preservation has undergone extreme changes in recent years. Only in the last few years have schools, businesses, and the public been interested in preserving historic sites. Prior to this involvement, historic preservation was accomplished by a few individuals and patriotic groups. Since the field is relatively new, little has been researched and written regarding the early efforts 
of preservation. One man who emerged as a leader in the preservation movement in Oregon, for over thirty years, was Burt Brown Barker.

This thesis, through research of the files associated with five different preservation projects, examines the role Barker played. In each case, an exhaustive search was made of all the files and scrapbooks housed at each institution. In addition, using contemporary newspaper accounts, Barker's unpublished autobiography, and several books relating to historic preservation, a careful examination of Barker's role can be made.

An analysis of the research shows that the role Barker played in historic preservation was a significant one. His contributions to the preservation of historic pioneer sites in Oregon remains a lasting memorial to the determination of this man. Though his name is relatively unknown, this thesis shows that he deserves to be recognized and remembered for his efforts. 


\title{
BURT BRUWN BARKER\&
}

HIS ROLE IN HISTORIC PRESERVATIUN IN UREGUN

\author{
by \\ MARK FREDRIC PETERSUN
}

A thesis submitted in partial fulfillment of the requirements for the degree of

\author{
MASTER OF ARTS \\ in \\ HISTURY
}

Portland State University

1983 
TO THE OFFICE OF GRADUATE STUDIES AND RESEARCH:

The members of the Committee approve the thesis of Mark Fredric Peterson presented November 22, 1982.

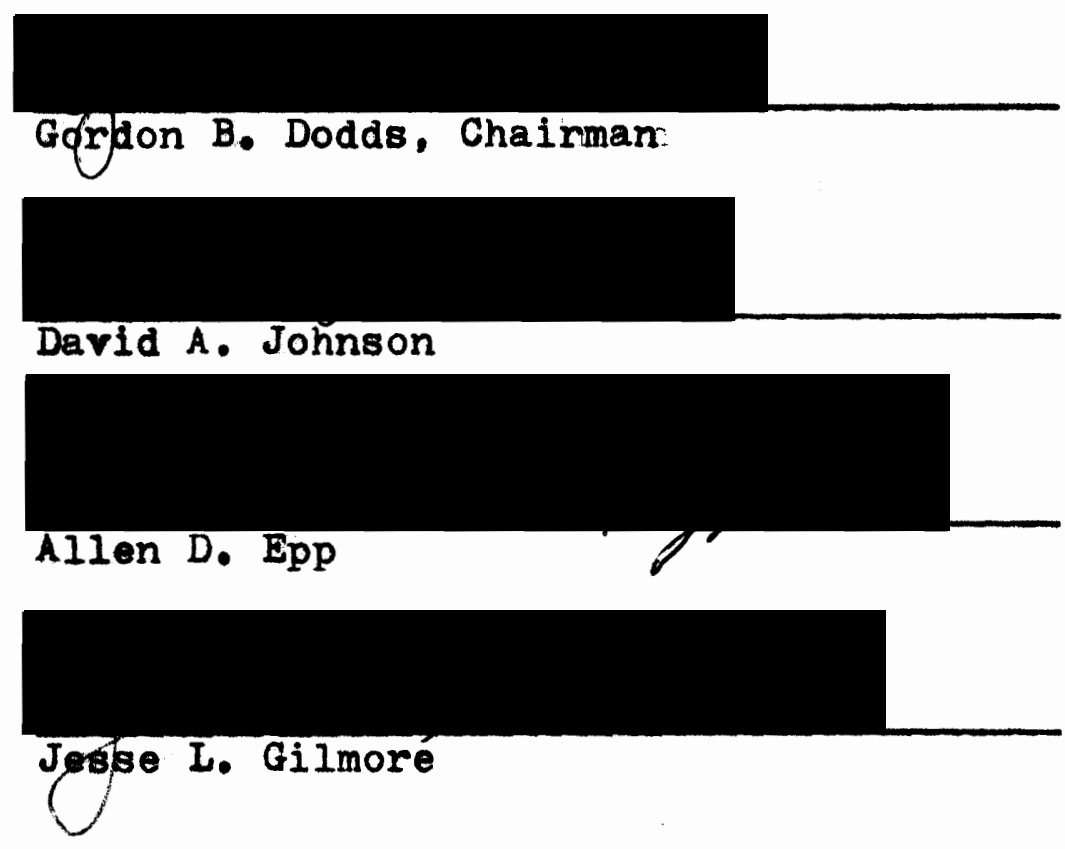

\section{APPROVED\&}
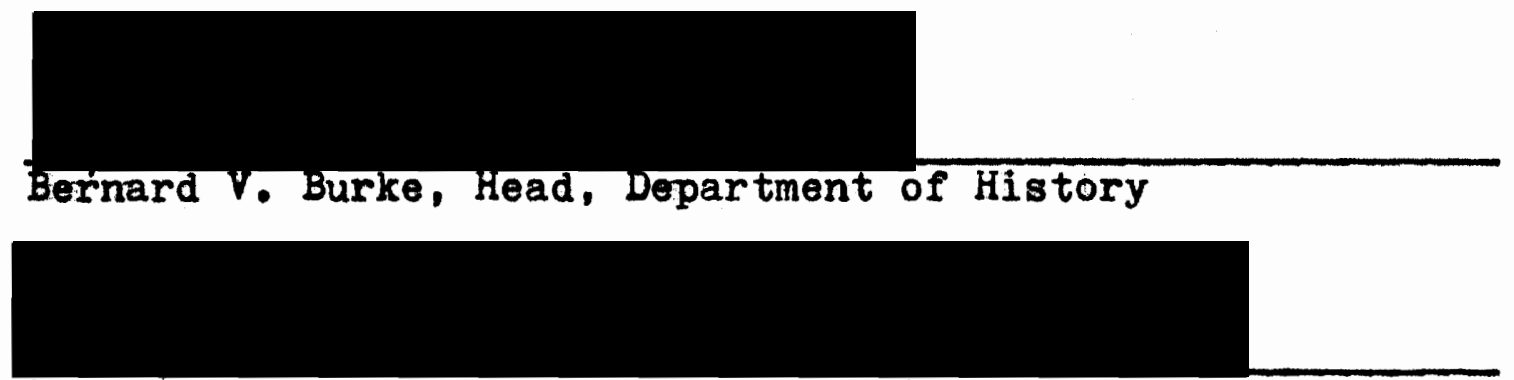

Stanley E. Rauch, Dean of Graduate Studies and Rersearch 


\section{ACKNOWLEDGEMENTS}

I wish to thank the members of my committee, Gordon Dodds, Allen Epp, and David Johnson for their patience and guidance: Mrs. John Sprouse for her assistance and encouragement to write about her father, Deborah 0lsen and Terence $0^{\circ}$ Donnel for reading portions of the thesis and giving their comments, Daniel Robertson for his help with the proofreading, the staffs and members of the boards at the McLoughlin Memorial Association, Mission Mill Museum Association. Herbert Hoover Foundation, and the Aurora Colony Historical Society for their permission to research their files, and most especially my wife Kathie for her help and support. 
TABLE UF CONTENTS

page

Acknowledgements ............................. iii CHAPTER

I Introduction........................... 1

Early Preservation in the United States..... 2

Early Preservation in Oregon............? ?

Burt Brown Barker..................... 11

II The Parsonage, Salem..................... 16

III The McLoughlin House, Oregon City............. 39

IV The Minthorn House, Newberg................ 63

$\checkmark$ Fort Clatsop, Astoria..................... 82

VI Ox Barm Museum, Aurora..................... 95

VII Summary and Conclusions.................... 115

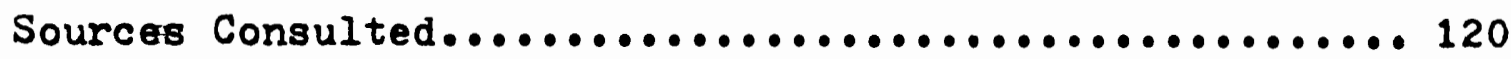




\section{CHAPTER I}

\section{INTRODUCTION}

Groups are recognized and remembered frequently for their accomplishments, while their leaders are often forgotten. One man who was actively involved in historic preservation in Oregon, but whose name is unfamiliar to many, is Burt Brown Barker. As a leader or member of many groups Barker was involved in several preservation projects spanning more than thirty years.

This thesis will show that Barker's role in preservation was influential and original in the state of Oregon. He became aware of preservation needs, acted to solve them, and did so often against great odds. By his actions and those of others the climate for future preservation was set. An examination of Barker's methods and motives will provide answers and encouragement to those interested in historic preservation today.

Due to Barker's efforts, Oregon has many historic landmarks important not only to the understanding of Oregon history; but also to that of American and European history. Furthermore, because of his work people today have a better understanding of the reed for studying, supporting, and preserving our irreplaceable historic properties. This paper 
is a history of those projects in which Barker was directly involved. To better understand and appreciate Barker's contributions, it is necessary first to be aware of the development of the preservation movement in the United States and in Oregon.

\section{EARIY PRESERVATION IN THE UNITED STATES}

The preservation movement in the United States naturally began in the East, where most of the older homes and historic sites were located. The East also had the largest concentration of people and money. As early as 1813 some people were volicing concern about preserving Independence Hall in Philadelphia, Pennsylvania. In Newburgh, New York, Washington's Revolutionary War headquarters, the Hasbrouck House, was saved in 1850. Andrew Jackson's home near Nashville, Tennesece was restored in 1856.

The preservation movement was unofficlally born on March 17. 1856, with the chartering of the Mount Vernon Iadies' Association. They were the most significant national preservation organization created to that time. Much of the credit belongs to Ann Pamela Cunningham, who successfully publicized the first nationwide preservation campaigns the effort to save the home of George Washington. Possibly even more important than this noteworthy task was the fact that

... from the ranks of the younger lady managers of the Mount Vernon Ladies' Association were to come 
the leaders or parents of the leaders of the great wave of patriotic associations in the $1890^{\prime} \mathrm{s} .1$

Historian Robert Woibe wrote in The Search for Order that in the $1890^{\circ} \mathrm{s}$ there was a "splintering process" at work in American society. He attributed this to the rapid industrialization and urbanization that was taking place. Immigration patterns were changing and the Anglo-Saxon. Protestants wanted to maintain a sense of the old community.

Two of the early preservation groups in the United States were the Daughters of the American Revolution (D.A.R.) and the National Society of Colonial Dames of America. Both groups were started in the early 1890's. Their membership requirements specified certain genealogical qualifications. The D.A.R. required that an ancestor had fought in the American Revolution. Members of the Colonial Dames had to trace their ancestry to an individual in colonial America who made a significant contribution. Both groups were involved in preserving United States history, but with distinct differences between them. The D.A.R. was much larger and was mainly interested in saving buildings associated with Revolutionary War heroes and their cemeteries. The Colonial Dames, on the other hand, were

1

Charles B. Hosmer, Presence of the Past (New York: G.P. Putnam's Sons, 1965), P. 57.

2

Robert Weibe, The Search for Order. $1872-1920$ (Now York, Hill and Wang, 1968), 2nd Ed., pp. 44-75. 
interested in sites of national historic interest. "The Colonial Dames had one goal in common with the D.A.R. - the education of children and immigrants." 1 This educational purpose was to instill patriotism among the citizens of the United States. Preservation, they believed, was one way to accomplish this goal. Many of the buildings saved by these groups later continued to serve democracy as meeting houses and museums.

Ann Pamela Cunningham compiled the early records of the association, making possible recording the history of the group. Her work in this respect was indeed exceptional, for "Many preservation groups founded long after the Mount Vernon Ladies' Association did not keep any significant 2 records." Therefore, knowledge about many preservation projects is incomplete. The projects and those who conducted them remain largely unknown.

Several important buildings were saved in the nineteenth century. The first to be preserved and administered by a historical society was the Benjamin Thompson house in Woburn, Massachusetts. Thompson, a scientist, was better known as Count Von Rumford. He was "...the first to

1 Hosmer, Presence of the Past, p. 138. 2 Ibjde. pp. $53-54$. 
determine that heat is a mode of motion." ${ }^{1}$ His house was preserved in 1877 through the efforts of the Rumford Historical Association. In 1898 the first house to be saved solely for its architectural value was the Whipple house in Ipswich, Massachusetts. Up to this time buildings were saved on historical criteria alone. To qualify, someone famous had to have lived there or it must have been the site of some famous historical event.

Another prominent figure in the early preservation field was William Sumner Appleton. Appleton founded the Society for the Preservation of New England Antiquities (S.P.N.E.A.) in 1910. Through his work, Appleton had a profound effect on the preservation movement, an influence that still continues. He was a pioneer in his belief that old buildings should be saved by any means possible, and that they need not always be used as museums. He advocated the rental and commercial use of houses. This adaptive re-use of buildings that Appleton supported had been unheard of up to this time.

The preservation movement in the South started in 1888 with the formation of the Association for the Preservation of Virginia Antiquities. This was "...the first large

1 The Dictionary of National Biography Brom the Beqinnines to 1900 (London i Oxford University Press, 1961). p. 1291.

2 Hosmer, Presence of the Past, pp. $237-259$. 
private preservation group to appear in the South after the Civil War." 1 The South was unable to finance preservation projects on the local level so they turned to the state and federal governments for help.

According to Hosmer "The Middle Atlantic States had some small local historical societies, much like those in New England, but most preservationists in this region turned to the state and city for aid. In the Midwest and the Par West the pattern of the Middle Atlantic area was most common. though there was an even greater emphasis on stateowned historic sites." ${ }^{2}$ Because the preservation groups were so spread out, there was very little cooperation among them.

The bulk of the early preservation work in the West occured in California around the turn of the century. Charles H. Hosmer, Jr. attributes this to the fact there were more historic buildings with which to work and that the population was growing fast enough to support the preservation programs. ${ }^{3}$ Most of the work centered around preserving the early Spanish missions. The organization most involved with preserving these missions was the Roman Catholic

1 Hosmer, Bresence of the Past. p. 65.

2

Ibjde. p. 301.

3

Ibide. p. 125 . 
Church. Outside of Califormia, "...preservationism in the Par West was widely scattered...."

One of the problems preservationists faced in the West was the fact that the buildings had not been well constructed. Most were built of wood and designed to fill a temporary need. For this reason many buildings were simply reconstructed instead of restored. Another obstacle that they faced was nature. Earthquakes frequently interfered with work on the California missions. In the Northwest, the damp climate created problems. Hosmer believes that "The most serious problem the preservationists faced in the West was the lack of geographical unity...." The buildings worth saving were too far away from the mass of the public and were therefore neglected.

\section{EARLY PRESERVATION IN OREGON}

"The preservation movement in Oregon, was launched in 1900, by the Oregon Historical Society and the Oregon Pioneer Association." ${ }^{3}$ These groups were looking for the site where settlers formed the Provisional Government in

1 Hosmer, Presence of the Past, p. 130. 2 Ibide, p. 124.

3

Elisabeth Walton Potter, "Historic Preservation in Oregon - A Preliminary Report," Oregon State Highway Division (April, 1971), p. 1, author's file. 
1843. The Oregon Pioneer Association erected a marker at Champoeg Park in 1901 to commemorate this event.

Another early project in Oregon was the saving of Dr. John McLoughlin's home in Oregon City. Chief Factor of the Hudson's Bay Company. McLoughlin was one of the most influential men in the early history of the Oregon Country. This house was moved several blocks in 1909 to a park dedicated in McLoughlin's honor. The house was finally restored in 1935 by the Mcloughlin Memorial Association. In 1941 the National Park Service designated it as a National Historic Site. However, it was not until August 30, 1950 that it was officially dedicated. 1

In 1911 a tribute was given to Oregon's first Superintendent of Indian Affairs, General Joel Palmer, who was the founder of Dayton. "The Blockhouse which overlooked Fort Yamhill on the perimeter of the Coast Indian Reservation from 1856 through the Civil War...was...reassembled in Dayton City Park." The United States government had granted permission to the city of Dayton to move the blockhouse. On the night of Friday, June 9, at $90^{\circ}$ clock, a procession of Indians, teams and wagons drove into Dayton with the first logs, over which floated the American flag.

1 "Notes," Orecon Historical Quarterly, September, 1950, Vol. II: No. 3. p. 228.

2 Potter. "Historic Preservation in Oregon - A Preliminary Report," p. 1. 
The flag was left unfurled until the last of the wagon train had halted near the middle of the park where the blockhouse was reconstructed." 1

There were many cominemorative plaques placed at historic sites in Oregon during the $1920^{\prime} \mathrm{s}$ by the Oregon Chapter of the D.A.R. Many of the historic structures in Oregon were recorded by the Pederal Government in 1934 as part of the Historic American Building Survey.

Out of these and other activities largely commemorative in emphasis prior to passage of the National Historic Sites Act of 1935. there evolved a broader interest in local history in Oregon, a foundation for later accomplishments.2

The Historic Sites Act was the first bill passed by Congress which coordinated planning for the protection of historic sites. The agency given this responsibility was the National Parks Service. The Historic Sites Act

...called for the creation of a national survey of historic sites, it encouraged cooperative agreements with private and governmental bodies for the maintenance of those sites, and it empowered the secretary of the interior to accept properties as part of a system of national historic sites, with the benefit of the collective expertise of a new

1

"A Bit of Barly Day Precaution," clipping, April 16; 1939, Oregon Historical Society (O.H.S.). Verticie Pile, Yamhill County.

2

Potter, "Historic Preservation in Oregon - A Preliminary Report," p. 1 . 
group to be called the Advisory Board on National Parks, Historic Sites, Buildings, and Monuments.1

With the passage of the Historic Sites Act in 1935. the "...federal government had suddenly become a critical element in the historic preservation movement, and there was no turning back." The Historic Sites Act was a popular idea which found its roots in the Great Depression, when people were looking for a sense of place and the government was interested in tapping the large force of unemployed professionals. Before the passage of the Historic Sites Act there were few people who were making a living working in historic preservation.

When John D. Rockefeller, Jr. told W.A.R. Goodwin to hire an architect to sketch out a plan for a fully restored Williamsburg in the fall of 1926, there was no professional in the United States who supervised restoration work on a regular basis.3

Restoration work up to this time was done by local groups of dedicated volunteers, or by large regional or national organizations. This transformation in preservation during the $1930^{\circ} \mathrm{s}$ did not mean the ond of local individuals playing a significant role in preservation.

1

Charles H. Hosmer, Jr., Preservation Comes of Age, From Williamsbure to the National Prust, $1926-1949$ (Charlottesville: University Press of Virginia, 1981), Vol. I, p. 573.

2

Ibide, p. 576 .

3

Ibide, Vol. II, p. 866. 


\section{BURT BROWN BARKER}

One man who became involved in historic preservation in Oregon during the $1930^{\circ} \mathrm{s}$ was Burt Brown Barker. Barker was born in Waitsburg, Washington, on November 3, 1873, of early Oregon pioneer parents. His mother, Blmira Chadwick Brown, was three when she crossed the Oregon trail in 1847 . Her father, Elias Brown, died along the way. His wife continued with her father, Barker's great-grandfather, Thomas Cox, who became the first merchant in Salem.

At one year of age Barker went to live in Halsey, Oregon, with Mrs. Henry Penland, his aunt.

I lived there until the spring of 1879 when I went to Salem, Oregon to live with my mother. She had meanwhile divorced my father. William Clement

Barker, and married David Iayson Matheny. I lived with them until in 1893 when I went to the University of Chicago.1

In 1843, Matheny's parents had come to Oregon with the Applegate wagon train. Barker's stepfather was born in Oregon in 1844. Much of the early history of Oregon Barker learned from these relatives.

Barker attended Willamette University, beginning in 1891 and while there he "seemed to blossom rather rapidly."

1

Burt Brown Barker, Autoblomaphy of Burt Brown Barker (Portland, 1965), Introduction. Five copies of this book were published at the author's expense for his family.

2 Ibide, p. 27. 
He became business manager of the student mewspaper and was on the school debating team. Barker entered the University of Chicago in 1893. He worked his way through school at various jobs around campus and was active in the debating club. He graduated in 1897 and returned to Oregon, where he eventually found a job teaching English and mathematics at McMinnville College (now Iinfield College). After one year at this job, he was accepted by the Harvard University Law School and was graduated in 1901. Following graduation Barker toured Europe with some of his classmates. After returning from Europe, Barker found work in a law firm in Chicago.

On June 15, 1904, Barker married Ella Merrill in Chicago. His wife was born in Davenport. Iowa, brought up in Hartford, Connecticut, and was living with her parents in Chicago at the time. Her father was the first Western agent for Aetna Insurance Company. Mrs. Barker was a proud member of the Mayflower Descendants.

Barker showed considerable skill as a lawyer and made a name for himself. He was instrumental in starting a volunteer program whereby lawyers defended indigent persons accused of crimes. He helped end some of the abuses which took place in the Cook County fail. This work brought Barker to the attention of the Chicago Bar Association and he became its secretary in 1916. He changed the by-laws of the association which forbade lawyers from joining until 
they had been practicing law in the state for a certain 1 period of time.

More and more of the corporate legal work Barker was doing at this time required his presence on the east coast. For this reason he moved to Montclair. New Jersey, in 1918 , and practiced law in New York City. Barker was the chief attorney for Jones and Baker, a large Wall Street brokerage firm. After several years the strain became too much for him. Barker retired in 1922 and he and his family took a trip around the world, returning in 1923. In 1926, on the advice of his doctors, Barker, his wife, and their seventeen year old daughter. Barbara, went to Europe for a year.

Upon returning. Barker went to Oregon to settle some of his father's financial problems. He expressed an interest to some friends that if the right job were available he would be interested in moving back to Oregon. His name was mentioned to the president of the University of Oregon, Arnold Hall, as a possibility for the position as dean of the Law School. This job was filled, but Barker was offered the position of vice-president, which he accepted. Barker, his wife, and his daughter moved to Oregon in 1928. His nominal salary was used for civic projects, including the "Pioneer Woman," a statue on the University of Oregon campus inspired by the experiences of Barker's mother crossing the

1

Barker, Autobjerraphy, pp. $79-83$. 
Oregon Trail. Barker had made wise investments which enabled him to retire financially secure at fifty-five. Barker gave his reasons for retiring from law in his autobiography. While touring Bngland, in 1901, he chanced to stay a night with a man who happened to be the mayor of a small town. He explained to Barker that his father had impressed upon him that

...his study of law would be the first part of his life but that he must make it lead into the last part of it, otherwise the life was not a whole, but merely two parts, and as such they did not make a whole unless they were 80 planned.1

The first years of the mayor's life were spent preparing himself for the legal profession. He then spent twenty-five years in accumulating wealth. He was then able to retire at age fifty and go into politics, for which he had been preparing himself while a lawyer. Barker remembered the effect of this chance encounter. "I am quite frank to say that that experience made a lasting impression on me."

While he was an attorney in Chicago Barker had one experience which confirmed the wisdom of the mayor. He had begun to take on public matters in his spare time. His employer, Mr. Wolseley, obfected and asked him to change. "I had to face the question - - should I? I decided not to change and as a result I left the firm and went on my

1 Barker, Autobierraphy, p. 101.

2 Ibide, p. 102 . 
1

own." Later, when Barker was secretary of the Chicago Bar Association, his former employer, Mr. Wolseley, retired and asked to be appointed to a committee of the association. He was turned down because he had not been involved before. Barker died in Portland on January 29, 1969. His career in public service spanned more than four decades. During his "retirement" yors in Oregon he served on numerous boards of directors; wrote several books and articles dealing with Oregon history, served as the director of Public Works of Art Project for Oregon, Washington, Idaho, and Montana, 1933 - 4, was the regional art director for the Pederal Works of Art Project in the Northwest, 1935 8, and was president of the Oregon Historical Society. He received two honorary degreess one from Linfield College in 1935 and one from Pacific University in 1965. Not until he was over gixty years of age did he become involved in historic preservation. The main projects in which he was involved were the McLoughlin House in Oregon City, the Minthorn House in Newberg. Port Clatsop in Astoria, the Ox Barn Museum in Aurora, and the Parsonage in Salem. 


\section{CHAPTER II}

\section{THE PARSUNAGE, SALEM}

The first historic project in which Barker became involved, and one to which he devoted a lifetime, was saving the old Methodist Parsonage in Salem, Oregon. Barker had been brought up in the Methodist religion, and later inherited the building from his father. Barker realized that the history associated with the Parsonage was important to the development of Oregon.

The Oregon Methodist mission was the first Indian mission established in the Pacific Northwest. The Reverend Jason Lee arrived in 1834 and established his mission at what was later called "Mission Bottom." Lee was successful in persuading the Board of Managers of the Missionary Society in New York to approve the sending of additional personnel and supplies to expand the mission program throughout the Columbia River Basin. In June 1840 the "Greet Reinforcement" of fifty men, women, and children arrived on the Lausanne.

Most of the mechanics were dispatched to a creek on Chemeketa Plain within the present site of Salem, some ten miles south of the original mission station. There they began to build a saw mill and 
grist mill.1

The following year it was decided to build "...the new Oregon Mission Manual Labor Training School for the Indians and a parsonage for the Director of the School and Preacherin-Charge of the Willamette Station." ${ }^{2}$ The Parsonage was used as a classroom until the school was completed. After a few years the school was taken over by the Oregon Institute which kept an interest in the Parsonage.

The Methodist Church retained control of the Parsonage until 1865, when it traded the building to the Willamette Woolen Manufacturing Company for other property. The building, during the period it was owned by the church, was the site of several meetings concerning the formation of a provisional government. The building had been enlarged in 1849 by Superintendent Willima Roberts to "...allow two families to "reside in it entirely distinct." 3 He shared the house with J.H. Wilbur, Principal of the Oregon Institute.

The Willamette Woolen Manufacturing Company leased the property to the Pioneer 011 Company on August 12, 1867, for

1 Elisabeth Walton Potter, "Chronology," Author's file or Mission and Mill Museum Corporation, p. 1. The organization's name was later changed to Mission Mill Museum Association (M.M.M.A.).

2

Ibide, p. 2 .

3

Ibide, p. 3. 
a period of ten years. At some time in the next ten years the house "was removed from its original site near the northwest corner of the existing Thomas Kay Woolen Mill to Lot 5, Block No. 30 of the University Addition (1325 Ferry. Street)..... According to Barker.

0ld 'Dean Wright' came to its rescue and bought it for $\$ 100$ and saved it by moving it.... Here it was converted into two apartments and a lean-to kitchen built on the north end.2

In 1896 William Cosper acquired the property on which stood the Parsonage. This event begins Barker's involvement with the house.

Barker's father, William Clement Barker, lived in Salem and rented from Cosper. Barker remembered Cosper as ...a big, heavyset Englishman of recognized wealth. He was the backer of the Gilbert Brothers Bank in Salem. After the death of Mr. Cosper, my father and 8 tepmother took possession of the entire property. It consisted of four houses and a barn. which they mortgaged on March 1,1904 for $\$ 400$. They contimued to live in the corner house and rent the others.3

Barker, although living in Chicago at this time and practicIng law, returned to Oregon frequently to visit his mother and stepfather who lived in Salem. He would also go to see his father and stepmother.

1

Potter, "Chronology," p. 4.

2

Barker, "The Lee House and the Parsonage," n.d., p. 2, M.M.M.A. files, Salem, Oregon.

3

Barker, Autobierraphy, p. 240. 
On one of his visits in 1913 Barker recalled that his father asked him to go with him to see a lawyer.

He gave me no clues as to the nature of the visit: We went to the office of an attorney... where the lawyer... gave me the sad story of my father's financial condition. In short there was a mortgage several years past due with accumulated interest, special street paving assessments on both Ferry and 13th Street unpaid with heavy penalties. The attorney said he was on the point of foreclosing and disposessing my father and stepmother unless the entire amount was paid. He said it would cost about $\$ 6000$ to pay all indebtedness to date. 1

Barker suggested to his father that he would pay the money on the

...condition that both my father and his wife join in a deed of the property to me retaining unto both and the survivor a life estate with right to collect the rents and out of it pay the taxes and insurance and have the remainder for their own keep. 2

In order to assure himself that his stepmother's heirs would not think he was trying to take advantage of them, he suggested that she write her relatives and tell them about the proposed transaction. They were given a chance to make the same offer but no one came forward. On January 2, 1914, the property was deeded to Barker.

After Barker's stepmother died, her niece, Mrs. Sadie Jepsor, and her family, moved into the house and took care of Barker's father. Jepson took care of the house and collected the rents from the other houses. Barker's father

1

Barker, Autobjoeraphy, p. 240.

2

Ibide. p. 241. 
died on December 11, 1923 while Barker was on a trip around the world. His father left a will giving his entire estate to Jepson. Barker's attorney notified Jepson

...that all the property had been deeded to me in 1914 and that the rents were mine. He told her to continue to live in the house, collect the rent and put it in the bank in my name and await my return from my trip. Meanwhile she probated my father's will and reported no assets.1

When Barker returned from his trip he landed in San Francisco and went directly to Salem. Jepson was anxious to buy the house and Barker agreed to sell it. He accepted her appraisal of $\$ 8,500$ and signed a contract for that price. The terms were $\$ 500$ cash and $\$ 300$ sach six months with interest at $5 \frac{1}{2} \%$ per annum. Barker signed the contract on April 30, 1924. He was living in New Jersey at the time. After receiving only two payments, Barker was asked by Jepson for a one-year deferment. This was agreed to. Barker in his autobiography recalled. "She made no further 2 payments." The matter continued to drag on until 1928 when Barker returned to Oregon. He then visited Jepson and asked about the payments.

Ore of her children was seemingly musically inclined. I talked to his teacher who assured me that the boy had promise and so I volunteered to

1 Barker, Autobioraphy. p. 241. 2 Ibide, p. 242 . 
continue the period of suspension of payments.1

Barker remembered the boy graduated, married, and abandoned his music. He never heard of him again.

In early 1935 Barker heard from Chester Cox, a cousin in Salem, that the property had been posted for sale for taxes. Barker rushed in and paid them, all penalties and interest and "...then insisted that the Jepsons cancel their contract and quit claim the property to me. This they did under date of March 11, 1935. $0^{2}$ It was during this time period that Barker decided that the house should be recognized for its historic significance.

Barker hoped to interest Willamette University in the house because the meetings which led to the founding of the school were held in the old Parsonage. Barker first wrote to Bruce Baxter, president of the university, on February 25. 1935, and told him that he had recently visited the

\section{Parsonage.}

It is teneted by people who have no knowledge of the historical significance of the building and it certainly looks like the rag tag end of nothing....

A bout it clusters all of the early history of Methodism in the Pacific Northwest and with the tenants ousted and the excrescences (such as the lean-to kitchen) scratched off and the house properly cleaned and restored to its original condition, no one would know that it had been badly misused. It certainly is to be regretted that a building of such historical importance has been

1 Barker, Autobierraphy, p. 242.

2 Ibide, p. 242 . 
allowed to be occupied in this fashion. However the work of a good architect, carpenters and painters can restore it to its original condition.... I venture to affirm that there is no building standing in the Pacific Northwest with the historical significance of this one and it would be too bad to have it lost simply because at the present time it happens to have some old and unattractive washings on the front porch.1

After apparently receiving no response from the university, Barker again wrote to Baxter, this time at greater length about the historical significance of the house. He started by saying, "Do you know I have a notion to get enthusiastic about the 'Parsonage'?" He went on to point out how all the other early Salem buildings were gone "...excepting only the Lee house, which, while older by a few months, is less 'important in point of educational interest"." Barker was more specific about his ideas for the house.

I can think of nothing now which would give me greater pleasure than at my own expense to restore that building as nearly as possible to its original condition and place it on the campus of Willamette University there to remain as an historical monument of the beginnings of Christian education in the Northwest..2

In his efforts to save the Parsonage, Barker continually: stressed the importance of the building. He felt

\section{1} Barker, Ietter to Bruce Baxter, 25 February 1935, M.M.M.A. Piles.

\section{2}

Barker, Letter to Bruce Baxter, 20 March 1935, W.P.A. flles, Historic Bulldings, Marion County, State Iibrary, Salem, Oregon. 
rather strongly that the Parsonage was much more historically significant than the Lee House, or for that matter, any other building in Salem. Barker felt that because many Methodist meetings were held in the Parsonage, it "...was more intimately associated with Willamette than the Lee house was."

Barker visited President Baxter and each member of the Bxecutive Committee of the Board to make the same offer with the house.

All seemed favorably inclined. I even discussed it with Congressman Willis Hawley of the Board, who seemed to favor it. But always there was procrastimation and holding off. On March 1, 1940 I wrote to Paul Wallace of the Willamette Board and again renewed my offer to move and restore at my own expense. I never received a direct answer from the Board to my letter but under date of November 22 , 1940. I received a letter from Paul Wallace in which he says, 'As to the matter of placing the Parsonage on the campus, I have not seen Mr. Belluschi's report, but I understand that his position was very positive that there was no room for it, all space being already allocated in the plan which he had submitted for the future development of the University, which plan has been accepted by the Board.... It was the old story of an architect being unwilling to see his plot plan altered even for the preservation of an historic monument.... All my plans failed and on or about July 1, 1940 after. I had worked for 5 years to give the house to someone to preserve it. I finally sold the entire property to Roy $M$. Locken Louchenour and reserved the right to remove the Parsonage at any time within two years. I then spent the next two years trying to find a home for it and had one near miss but

1 Library.

Barker, Letter to Bruce Baxter, 20 March 1935. State 
always it was a question of money and location.1 The removal time expired and Barker still had not found a permanent place to put the house. He convinced Louchenour to extend the removal time for two more years.

The house remained on the property until shortly after It was sold to the Salem School Board in 1953. The Marion County Historical Society, to whom Barker had given the title, was given notice to move the building within thirty days, or it would be destroyed. Barker credited Murray Wade, president of the Marion County Historical Society, for coming to the rescue at this time. Wade found a place for the building on the "Kay Woolen Mill Mills property less than 100 feet of where it stood originally." Barker contributed $\$ 500$ to the moving expenses, the balance came from the Women's Club of Salem and the Marion County Historical Society. The building was moved the day before the time expired. The same people later contributed to move the building again when the site it was on was made into a parking lot. On this occasion the move was just a short distance.

The house was only tentatively located and much more was needed to develop it into a museum. Barker continued his efforts to get the house restored. He wrote to Mrs.

1

Barker, Autobiography, pp. $243-244$.

2

Ibide, p. 244 . 
Howard N. Hunsaker, president of the Women's Club of Salem,

... I fear that Salem will lose its most sacred shrine unless some action is taken immediately.... I fear that Salem will have no shrine worth talking about so far as I know.1

Barker in the June 1955 issue of Marion County History asked.

What do we do? Salem has two parks - Willson Avemue and Marion Square. The Parsonage could be moved to either, restored, surrounded by a simple white picket fence, and bordered by flower beds, and cared for at little expense by those who care for those parks...the Parsonage would become the most sought after house in the city, and the Marion County Historical society could be the custodian and have a home of which it could be proud. I am satisfied this could be done for a few thousand dollars. I believe that Salem is as patriotic and as interested in its past as any city and would support a movement to aid the school and city authorities to preserve the Parsonage and watch it become a shrine. I am so convinced of this that I hereby give evidence of that faith by offering to start a public subscription with a pledge of $\$ 500.2$

The Marion County Historical Society began investigating other ways of restoring and keeping the house. Negotiations between the Society and the State Fair Board were held to discuss placing the building on the fairgrounds. HeIen Pearce, an officer of the Marion County Historical Society. wrote Barker and explained the situation with the building.

The Marion County Historical Society for more than a year has investigated the raising of funds by which

1

Barker, Letter to Mrs. Howard N. Hunsaker, 22 September 1953, M.M.M.A. Iles.

2

Barker, "The Parsonage: A Heritage," Marion County History. I (June 1955). pp. $3-5$. 
to set the house on the Pairgrounds.... At length, the society regretfully decided that the placement and restoration of the house would be quite beyond its financial capacity. The Soclety then notified the State Fair Board that it was willing to surrender ownership of the Parsonage if the Board would do the moving, the placement, and the restoration of the building. The Board agreed to take this total obligation.... With the Bill of Sale which, as I understand it, goes to the State Fair Board this week, will be a letter stating that the Historical Society will use its best efforts to provide appropriate furnishing of the Parsonage, once it is settled upon the Fairgrounds, and will also provide staff to receive visitors in the house during State Fair Week.1

At the time the Parsonage's movement to the fairgrounds was under consideration, Thomas Vaughan, director of the Oregon Historical Society became involved. He visited the building and later wrote to Marion D. Ross, of the University of Oregon School of Architectures

My essential opinion is that the plan to remove the structure to the State Fair Grounds is a solution which must be kept in mind, although it is not the best answer. The Fair Commission has made a very generous proposal, but they do not operate all year. In this climate the Parsonage could remain open all year. I wonder if it should therefore be moved so far out of the center of things. If it were, a very firm contract for the future would have to be provided. I also wonder if it could be given all

the care it would need, or if it would be worthwhile to repair and furnish it when the touring hours were 80 few and far between.2

1 M.M.M.A. files.

Helen Pearce, Letter to Barker, 2 October 1958,

2

Thomas Vaughan, Letter to Marion Ross, 24 March 1958, M.M.M.A. Piles. 
In 1958 the Marion County Historical Society went so far as to put in a foundation at the fairgrounds when it was stopped by the legislature. In December 1958 the Bill of Sale was given by the Marion County Historical Society to the Oregon State Fair Commission.

At the last minute the Attorney General found a reason to prevent it even after we had the Iegislature amend the charter of the Fairground Association so as to give it the power to accept the building.1

According to the Capital Journal “...the Fair Board got tangled up in red tape, changed its mind and handed the building back over to the society." ${ }^{2}$ The legislature did not want to take on the responsibilities of restoring and maintaining the house.

The Society then went searching for another solution for the location of the house. Barker talked with E.C. Sammons, president of the United States Mational Bank in Portland. Sammons told Barker about the will of William Walton, former vice-president of Ladd and Bush Bank, which established a trust fund of $\$ 6,000,000$ to be used for charitable purposes in Salem.

Within one week after I was told of this trust, the directors of the Marion County Historical Society called me to Salem and at a dinner said they were helpless and could not continue to manage the

\section{1} Barker, Autobiography, p. 244. 2 Scott McArthur, "Jason Lee Museum Planned," Capital Journal, 22 Pebruary 1961, clipping, M.M.M.A. files. 
Parsonage and asked me to please take it off their hands. I told them of the new Walton trust. Mr.

David Duniway knew of it but did not think we could touch it.1

Duniway, board member of the Marion County Historical

Society and the State Archivist, felt a permanent site was needed before approaching the Walton trust fund.

Barker then contacted Governor Mark Hatfield and told him about his plans for the Parsonage. The governor suggested getting a committee of Salem businessmen together to talk with the trustees of the Walton estate. A meeting was held which included the presidents of the Marion County Historical Society and Salem Chamber of Commerce, the city manager, the chairman of the parks commission, and other prominent citizens. At this lunch in the capital building Hatfield offered to serve as the honorary chairman.

The matter was discussed and it was decided that the Historical Society should suggest a chairman and then proceed and work with the others present to organize a strong committee. I thanked the Governor and thought that at long last we were on the right track. The President of the Historical Society appointed David Duniway, the State Archivist, the chairman - - and he did nothing and so the plan died before it started.3

1 Barker, Autobiosraphy, p. 244.

2

Telephone interview with David Duniway. Secretary of Marion County Historical Society, 27 October 1981.

3

Barker, Autoblography, p. 244. 
Barker continued to press for a solution. He next discussed the problem with Chandler Brown, a Salem resident and board member of the Oregon Historical Society. Brown was a business acquaintance of James Walton, a nephew and heir to the Walton estate. Brown agreed to discuss the Parsonage with Walton. He reported to Barker that Walton was sympathetic.

It was at this point that James Walton's daughter, Blisabeth, became interested in the house. She was a graduate student at the University of Delaware, specializing in historic preservation. She decided to do her thesis on the Willamette Mission and the surviving buildings, i.e. the Lee House and the Parsonage. Walton later expanded her thesis to include suggestions for locating the buildings. Her final recommendations were to move both the Iee House and the Parsonage to the Thomas Kay Woolen Mill property and develop it into an historical park.

In 1963 Barker conservatively estimated the cost of restoring just the Parsonage at $\$ 15,0000^{2}$ At this time when there were public discussions concerning where to put the houses and the raising of money to restore them, there

1 Elisabeth Walton, "Mill Place on the Willamett, A Nww Mission House for the Methodists in Oregon, 1841 $1844, "$ Unpublished thesis, University of Delaware, 1965. pp. $193-196$.

\section{2}

Helen I. Mershon, "Here's House That Faith Built," oregon Journal, 23 April 1963, clipping. M.M.M.A. files. 
appeared several letters to the editor in the Salem newspapers against such a move. Under the headline. "Shameful Thing." this letter appeared.

Spending $\$ 60,000-\$ 70,000$ on these old. unattractive buildings just to give them a home is a shameful thing. To think that the school children should be encouraged to help raise funds to achieve this thing is equally shameful. Or is it important that they learn to be fundraisers?1

One letter written by a "53 year resident" came up with the least expensive solution for the houses. He proposed,

... why not take a colored picture of each and preserve the enlarged picture? Perhaps take a few inside pictures also, and keep them where they can be seen. Preserving the two buildings would interest only a few, 80 why think of saving them.2

The Statesman came out against saving the Parsonage and the Lee House. This was the attitude of the newspaper's editor and publisher, Charles A. Sprague, ex-governor of Oregon. Sprague in a letter dated 1961 said.

I must confess I have not warmed up to this plan of saving the old parsonage. It is not the first housein Salem. That still stands at 960 Broadway. considerably altered. The parsonage has no architectural distinction, and George Washington mever slept there. My friend Dr. Burt Brown Barker is distressed that we haven't saved and restored the

1

Aaron E. Bowen, "Shameful Thing," Statesman, 8 February 1963. p. 4, clipping. M.M.M.A. files.

2

Lewis McKinney, "Pictures Not Houses," Statesman, 10 Pobruary 1963, clippling, M.M.M.A. files. 
parsonage, but-I fail to see that it qualifies for such distinction.1

In an editorial in February 1963 The Statesman took

the positions

With regret this newspaper parts with the Marion County Historical Society.... The dating, and the association of the figures who lived in them, are the only reasons to warrant considering their preservation.... The Parsonage is pretty much of a shell. Neither house has much architectural character:

As a practical matter their preservation doesn't register. The cost of moving, of restoration, the upkeep, the furnishing and guarding could be raised if there was clear sentiment for saving them. That has not been apparent.... It is sad to commit their heirlooms to the wrecker, but we drop out of line on efforts to preserve them.2

In the same paper there was an article stating that over 400 people turned out the day before to see the Jason Lee House, an event sponsored by the Marion County Historical Society.

The City Council of Salem was asked by the Marion County Historical Society to give its approval for saving the houses and finding a place for them on city-owned land, preferably Marion Square or Bush Park. The City Council was worried that the whole project would take too long and become an eyesore for the city. They were also afraid they

\section{1}

Charles A. Sprague, Letter to Harvey R. Tobie, 6 November 1961, O.H.S., Mss. 360.

2

"Early Salem Houses," Editorial, Statesman, 11

February 1963, clipping. H.M.M.A. Plles. 
would become responsible for some of the $\$ 70,000$ projected cost of restoring the two buildings.

The Capital Journal in its editorial on Pebruary 18. 1963 came out in support of moving the buildings to Bush Park because, "Bush Park already has Bush House, the scene of some history itself, and its best to keep our artifacts clustered." ${ }^{2}$ The City Council decided that the Lee House could be moved to Bush Park, and that if it was successfully moved and restored, then the Parsonage could be moved later. In August., the foint committee for the siting of the Parsonage and the Lee House, which was comprised of the Salem Planning Commission and the Salem Parks Advisory Board, recommended as its number one choice the Thomas Kay Woolen Mill property. The number two choice was the Lee 3

Mission cemetery. These were the recommendations made by EIisabeth Walton in her thesis study of the buildings. The Capital Journal reported, "The trustees of the Marion County Historical Society have asked the State Historical Society to set up a subsidiary organization to direct the project,

1

Floyd McKay, "Council Will Decide Fate of Wetherbeaten 123-year:old Jason Lee House," Statesman, 17 February 1963. clipping, M.M.M.A. Files.

2

"A Solution For The Lee Houses," Editorial, Capital Journal, 18 Petruary 1963, clipping, M.M.M.A. Files.

3 "Jason Lee House Iocation Suggested," Capital Journal, 27 August 1963, clipping, M.M.M.A. files. 
drawing representation from throughout Oregon: " ${ }^{1}$ Shortly after that the Salem City Council granted the Marion County Historical Society a year's extension on the temporary site of the Jason Lee House. In January, the Statesman reported that

...formation of the corporation recommended in a report to Salem City council last August, has been approved by an Oregon Historical Society committee ... and goes Jan. 10 to the board of directors.2

The City Council accepted the idea, but indicated it would not participate financially.

The Mission and Mill Museum Corporation was estabIished on October 5, 1964, as a mon-profit tax-exempt corporation. James Walton became its first presidentr Roy Harland, vice-presidenty Robert Powell, secretary, and Norma Langley, treasurer. Once organized it could start the restoration process for the two houses. On October 4 Barker had donated the first $\$ 1,000$ toward the restoration of the Parsonage. It was projected that they would need $\$ 400,000$ to complete the project. James Walton used his influence to get $\$ 110,000$ pledged for the property. This amount was enough to enable the corporation to purchase two and

1 "Historical Center Now Likely," Editorial, Capital Jounnal, 31 August 1963, clipping. M.M.M.A. files.

2

Ployd MeKay, "Corporation May Be Organized to Restore Two Pioneer Structures," Statesman. 2 January 1964, clipping, M.M.M.A. Flles. 
one-half acres on which the woolen mills property stood. It was purchased in Pabruary 1963, for $\$ 150,000$.

The corporation was going to have to satisfy its critics including Alderman Carroll Meeks, who the month before said.

We are condemning houses in the Front Street area that look better than the Jason le House. There is a piece of plumbing sticking out of the house that I'm sure Jason Lee approved personally.1

Meeks went on to suggest that certain panels and beams with historical significance re removed and saved, and the rest junked.

A technical committee was formed to investigate the restoration of the buildings. The members included. Frank Mattson, Regional Parks Agency, Marion Ross, Dean of the School of Architecture. University of Oregors Elisabeth Walton; Harry Iichter; curator Oregon Historical Society; Charles Hawkes, Salem architect, Wallace Kay Huntington, Portland landscape- architect; George Mcllath, Portland architect, and David Duniway. Duniway was selected as the chairman of the technical committee. Elisabeth Walton was named the chairman of the furnishing committee.

1 "Junking of Jason Lee House Called for by Alderman Meeks " Statesman, 29 September 1964, p. 5, cllipping, M.M.M.A. Files.

2 "Old Parsonage To Be Restored," Capital Journal. 23 Pebruary 1966, clipping. M.M.M.A. flies. 
Landscape plans were lald out by Wallace Kay: Huntington. The Gnow and Show Garden Club of Salem did the landscaping and provided the materials. The general contracting was done by George Johnston Construction Company, with Iyle Warren the master craftsman. Barker contimued to keep in touch with the progress of the restoration. He made frequent visits to the site.

Barker also was active in researching the history. He wrote to Duniway and Walton asking their help in writing a "...rather definite history of the Parsonage." ${ }^{1}$ Barker was writing from the hospital. He said that

...as soon as I...get back into my office and dig through the debris, I...plan to take up where we left off and push on to completion. I assure you that is my one main ambition now. It is strange how short time looks when one is in the hospital.

Barker went on to state,

But I hope we may be able to make the Parsonage an historical haven to which the political. educational, religious and socially minded citizens in Oregon may return to get satisfaction for labors well done and inspiration for future plans.2

Waltor's response to Barker pointed out that she and Duniway felt

...the Jason Lee house and the parsonage ought to be considered as a single unit of interpretation. Both structures are features of Thomas Kay Historical

1

Barker, Letter to David Duniway and Elisabeth Walton, 17 April 1967. M.M.M.A. files.

2 Ibid. 
Park. They are both 1llustrations of the same interpretive themes. Therefore we would hope that eventually both bulldings could be treated in a scholarly publication.1

Barker had set aside $\$ 8,000$ for the restoration work on the Parsonage. In May 1968 this money ran out and architect George McMath wrote to James Walton,

... Barker advised me that he had set aside $\$ 8000$ for completion of the work which, in addition to carpentry, included the heating, wiring and sprinkler system.... At that time I assured Dr. Barker that we would not exceed this budget. Due to the fact that the scope of carpentry work was impossible to determine it was agreed to proceed on a time and materials basis. It was further agreed that if the amount of carpentry work needed to complete the job exceeded Dr. Barker's budget, other funds would be used.... From the information that I have received it appears that the cost of work has exceeded the budget by several thousand dollars. In view of our understanding with Dr. Barker it seems proper that any monies expended since June 1967 in excess of $\mathrm{Dr}$. Barker's $\$ 8,000$ budget should be secured from other sources.2

Discovering that no one had secured a written bid for the carpentry work beforehand and that the budget Barker set had been exceeded, Duniway wrote to James Walton a letter of explanation. In it he said,

The work has been inspected by all of us, including Mr. Barker and his daughter, and I am sorry that somehow we were not aware that bills were not presented monthly; or informed that there was a ceiling on the carpentry budget. Some of the

\section{1}

Blisabeth Walton, Letter to Barker, 28 April 1967. M.M.M.A. Flles.

\section{2} M.M.M.A. Piles. 
decisions that we made undoubtedly swelled the cost, but they were the right decisions in terms of a real restoration. We strived to preserve and use the oldest trim designs, we attempted to be consistent in the restoration of wall surfaces and ceilings, and we even restored the glazing to the doors in the oldest cabinet which reflect the work of a ship's carpenter. If $\mathrm{Mr}$. Barker is unwilling or unable to assist us in paying the bill over and above the budget which Mr. McMath had estimated for him. I hope that we can promptly find other friends who will help pull us out of the financial dilemma that has developed. I stand ready to solicit funds for this purpose.1

Dumiway further stated that in the future he would appreciate written instructions.

McMath, to whom Walton's letter from Duniway was given, responded,

Your letter of May 14th to Jim Walton contains some exrors which I feel need clarification for the benefit of all concerned. The budget of $\$ 8,000$ for the second phase of work on the Parsonage was not based on my estimate. The $\$ 8,000$ was a fixed amount set aside by $D_{r}$. Barker for completion of the work as I stated in my letter to Jim on May 9th.... Bidding for the work was not considered for precisely the reasons you indicate in your Ietter.... I certainiy concur with this procedure and with all of the work that has been done.... As to not being aware that there was a ceiling on the carpentry budget, it is my recollection that this matter was discussed at our meeting on May 25...2

Barker was the one who first dreamed of restoring the house and was the one who in the end financed the

1 David Duniway, Letter to James Walton, 14 May 1968, M.M.M.A. files.

2

George McMath, Letter to David Duniway, 16 May 1968, M.M.M.A. files. 
restoration. "One of his final acts was to write a check to cover the costs of completion." ${ }^{1}$ His daughter Barbara was becoming increasingly involved as a result of driving her father to Salem. She helped in having a security system installed and an outside stairway built. Many persons were involved in donating or loaning furniture to the Parsonage, the bulk coming primarily from Ruth Powers, of Oregon City. Barker it appears, continued to fund the restoration, but died before the house was dedicated. His daughter, Barbara continued his interest in the house and was the one chosen to cut the ribbon on May 21, 1972. On the day it was dedicated there was a slight rain, but not enough to keep away almost 300 people.

Barker in his autobiography said,

Too much credit cannot be given to $\mathrm{Mr}$. James Walton for his foresight and drive in bringing the entire project to a head. When completed I am sure it will be a real credit to him and to the City of Salem.2

Barker understood that the project succeeded through the teamwork of many people and he himself was willing to remain in the background. It must have been a disappointment to those who worked with Barker over the years not to have been able to complete the project while he was alive.

\section{1} M.M.M.A. Mles.

"Mission Mill Museum" newsletter, Fnd of Summer 1972, 2

Barker, Autobjerraphy, p. 247. 


\section{CHAPTER III}

\section{MCLUUGHIIN HOUSE, OREGON CITY}

When Barker wrote about his involvement with the McLoughlin Memorial Association, he fondly titled the chapter "My Dr. John McLoughlin Days." Those "days" were actually years devoted to studying about an outstanding man In Oregon's history. Barker remembered this time as being the "Most productive period of my writing." 1 Indeed, Barker wrote and edited several books and articles about McLoughlin and his family. In his later years, Barker was considered to be the "...greatest living authority on Dr. John Mcloughlin." Not only was Barker the first to gain access to the Hudson's Bay Company's files, but also he singlehandedly tracked down dozens of original McLoughlin letters, while at the same time he played a major role in the preservation and furnishing of the Doctor's home in Oregon City.

1

Barker, Autobjegraphy, p. 149.

2

"To Your Health," prod. KGW - AM/FM, T.V. Broadcast about $\mathrm{Dr}$. John McIoughi in with Barker, McIoughlin Memorial Association (M.M.A.) files. 
MeLoughlin's home, built in 1846, was preserved for the sole reason that it was the home of someone famous. The architectural features of the house: were not a consideration. Marion Ross wrote in 1956 that the McLoughlin House ...is possibly the oldest house still standing in the State, and it is certainly the best preserved of its time. However, it is by no means typical of the architecture of the later forties.... The restrained form, small scale of the detail, the absence of any porch, and the general regularity suggest the late eighteenth century. It has strong analogies to some New England houses....1

McLoughlin was born at Riviere du Loup, Canada, in 1784. He studied medicine in Quebec, later choosing to go into the service of the North West Company in which he became a partner in 1814. When the North West Company merged with the Hudson's Bay. Company in 1824, McLoughlin was made the chief factor of the Columbia River Department, a position he held until 1846. McLoughlin is remembered by many as having been a good friend to the early missionaries and settlers. He also was well liked by the Indians because he treated them fairly.

Upon retiring. Moloughlin built his home in Oregon City, where he owned much land including the Imperial Mills. Oregon City had been incorporated by the Provisional

1 Marion D. Ross, "Architecture in Oregon, 1845 $1895^{\circ}$ Orecon Historical Quarterly. IVII, No. 1 (March $1956), 36-37$. 
legislature in 1845. McLoughlin did not find life there very easy.

His later years in the American community were neither happy nor prosperous, although he was probably the richest man in the country. His anguish over the death of his son John at Fort Stikine in 1842 - which he claimed, was a murder that Sir George Simpson refused to prosecute - and other disagreements with his superiors had hastened his retirement from the company and the loss of special emoluments of his office. He valued his properties at Oregon City at $\$ 500,000$ in 1849, but his early gifts of land to the missionaries had led to an invasion of his holdings by persons who contended that Mcloughlin held them on behalf of the company. Disputes over land titles embittered his relations with the Americans. Under the terms of the land laws applied to Oregon when it became a territory he was, in effect, dispossessed. In 1862, five years after his death, the State of Oregon made some restitution to his heirs and cleared disputed titles to Oregon City lots.1

The house in which Mcloughlin spent his last years was lived in by his widow, Marguerite, until her death on February 28, 1860. Following her death, the house was lived in by their daughter, Eloise, and her husband, Daniel Harvey until 1867. It was then converted to an apurtment house and was even used as a brothel for some time. It was this last use that would cause problems for the later preservationists.

In 1886, the Oregon Pioneer Association commissioned a portrait of Dr. Meloughlin. The portrait was presented to the people of Oregon on Pebruary 5, 1889. "It was accepted

1

Dorothy 0. Johanson, Bmpire of the Celumbia, 2nd. (New York: Harper and Row, 1967), p. 213. 
by Governor Sylvester Pennoyer and hung behind the chair of the President of the Senate." 1 This was the earliest public show of adoration, and the first attempt to preserve the memory, in some way, of this great man.

In the $1890^{\circ} \mathrm{s}$ a MeIoughlin Monument Fund was started by the Oregon City Rnterprise at the suggestion of F.X. Matthieu, an 1842 pioneer who was involved in the formation of the provisional government. It was hoped to raise $\$ 10,000$ to build some kind of monument. The sponsors did not know precisely what they were going to do, but a monument of some sort was needed to remind future Oregonians about Mcloughlin. The sum of only a few hundred dollars was actually realized. Those who were involved in this first attempt were later to become the mucleus of the group who would preserve his house.

A clipping in the files of the McIoughlin House reveals a letter to the editor from a Mrs. W.B. Zumwalt quoting the Oregon City Bhterprise, November 20, 1903

In honor of $\mathrm{Dr}$. McLoughlin, Oregon City Women's Club proposes to erect a monument. An effort has been started by the Oregon City. Lewis and Clark club to acquire ownership of the old Phoenix house, at one time the residence of Dr. John McLoughlin. The structure still stands on Main Street opposite the woolen mills, and is said to be the oldest building in historic Oregon City. If the present owners of the house will not donate the building for the purpose desired, the club will strive to raise the

1

Barker, "Address of Burt Brown Barker at internment of Dr. John MeLoughlin," 9 July 1948, M.M.A. files. 
necessary funds to purchase it. The building will be repaired and preserved in memory of the late $\mathrm{Dr}$. McLoughlin.... That the club failed in their efforts at this time was through no fault of, or lack of enthusiasm of those members who worked so faithfully, to fulfill their purpose; among whom I mention Mrs. Eva Emory Dye, the late Mrs. George A. Harding, Mrs. J.W. Norris, Mrs. Charles Miller and Mrs. Iinwood Jones, Mrs. Emma Galloway and many others, including the writer of this article.1

The house was sold in 1908 by. Mrs. J.L. Barlow and Captain J.T. Apperson to Hawley Pulp and Paper Company, for $\$ 6,000$. The Company soon announced it planned to raze the hone. At the suggestion of Mayor Walter Carll, the president of the company. W.P. Hawley, offered it to the city if the house was moved. This offer was accepted.

The citizens of Oregon City had had an opportunity to do so two years earlier when "the owners of the property offered to sell the building and grounds to the city." That drive was led by Mayor E.G. Caufield. "But on a referendum vote the proposition was defeated, as the city was in debt and the majority of voters considered it unwise to add another burden to it's finances." ${ }^{3}$

1 clipping, M.M.A. files.

"Mc.Ioughlin House," Oregon City Enterorise, n.d.,

2

"McLoughlin Home Saved," Oregon City Enterprise, 24 April 1908, clipping, M.M.A. files. 
The people of Oregon City were now faced with a situation of either moving the house or seeing it torn down. At first, the city proposed moving the house to the rear of some lots on Third and Main streets then occupied by the Cateract Hose Company.

Friends of the McLoughlin Home project advance the idea that the result would be improved if the House was placed on the front lot, and the hose company building moved to the rear.1

It was further suggested the upper floor of the house be rented, and the lower portion be used for municipal offices.

The Clackamas County delegation in the state Legislature, led by Representative J.W. Campbell, succeeded in getting an appropriation of $\$ 1,250$ passed by the legislature. This was half of what it requested. Governor George E. Chamberlain vetoed the bill. When this happened, the City Council passed a resolution stating,

The taxpayers of Oregon City should not be called upon to provide sufficient funds for the preservation of this memorable building, therefore be it... Resolved, That the City take care of the building until April 15th, 1909.2

If the private sector did not provide the funds, the city would tear the house down. A loud cry went up in the

1

"McLoughlin Home Stays," Oregon City Enterprise, 18 December 1908, clipping, M.M.A. files.

2

"McLoughlin Home May be Demolished," Oregon City Enterprise, 2 April 1909, clipping, M.M.A. files. 
Portland newpapers calling for saving the house and asking. "What will the pioneers do?"

On May 8, 1909, almost three weeks after the deadline passed, the McLoughlin Memorial Association was formed to raise money to save the house. The first president was former mayor E.G. Caufield. Plans called for raising $\$ 1,000$ to move the house to the city park at the edge of the bluff, known as Singer Hill. Ironically, this park had been given to the city by McLoughlin years before.

Almost immediately the Association ran into trouble. A petition was circulated which tried to prevent it from moving the house onto city property. The petition was signed by 202 people, but before it could be voted on, the house would have to be moved. Also, the measure did not specifically state the intention of its destruction or removal. An injunction was brought against the McLoughlin Memorial Association and the contractor F.S. Baker, attempting to stop them from moving the house. This suit was dismissed by Circuit Judge James A. Eakin.

There were many rumors circulating about what the Association was trying to do. The main objection seems to have focused on the fact that the house was at one time a brothel. The people living on top of the hill did not want it moved into their neighborhood. The house had also been allowed to become run down and to look somewhat dilapidated. The Oregon City Enterorise tried to set the record straight 
about what the Association had in mind. It pointed out that the house would be restored to its original condition. The editorial ended with the words. "Those who have cars to hear let them hear." ${ }^{1}$ Quickly $\$ 1,200$ was raised from people in Oregon City, members of the Oregon Historical Society, and pioneers befriended by Dr. Mcloughlin. When the last suit had been dismissed, the Association lost no time in getting the house moved. Many were worried that someone would try to burn the house down, thereby ending the matter forever. The contractor was quickly notified to proceed, which he did.

Moving the house to the top of the hill was no easy matter. "The engineers and house movers of Portland agreed that the only way the old house could be taken up the grade was to tear it down and rebuild it." ${ }^{2}$ At one point along the grade, the house was twice as wide as the road. A trestle was considered but was deemed economically unfeasible. The plan that evolved was that

... the house was loaded on $8 \times 10$ cross timbers with two $12 \times 14$ carrying timbers and when we reached the narrow point I shifted the outside carrying timbers in past the center of the house leaving slightly more than half of the weight extending over the embankment. The house was on jack screws. We lowered the jacks on the extreme outside until the

1 "Honoring His Memory," Oregon City mterorise, 25 June 1909, clipping, M.M.A. files.

2 C.I. Hastings, "The Moving of the McLoughlin House in Oregon City." M.M.A. files. 
weight Iifted the house off the inside timber next to the cliff, then loaded the inside of the house next to the cliff with sand, gravel and cement until the weight counter-balanced the overhanging and proceeded with it to the top of the grade and on the site it is now on.1

The opponents of the project hoped to get the house removed through the passage of ordinances no. 300 and 302 . They objected to the house being moved to a public park block without the consent of the voters. They circulated a statement that read

...it may be McIoughlin found it necessary to help some less fortunate that had suffered losses and hardships from their long journey westward, but it was not the widow's mite he gave but only crumbs from the rich man's table... McLoughlin the Hudson's Bay Company autocrat.

The paper went on to say that McLoughlin tried to obtain the land where Oregon City stands through

...misrepresentation and fraud.... McLoughlin's former home has been for past decades a haunt of shame and disgrace on South Main Street. It has been used for vile and disreputable purposes for so long that no decent, purity loving citizen can assoclate it with any good purpose. In a state of decay and dissolution it was dumped upon the city to disgrace a park block and destroy the most beautiful park site in our city - a white sepulcher, a wolf in sheep's clothing....2

The Statement further expresses its fears about nonresidents being involved, and the fact that

1

C.I. Hastings, "The Moving of the McLoughlin House in Oregon City," M.M.A. Piles. "To the Voters and Taxpayers of Oregon City." n.d..,
M.M.A. files.

2 "To the Voters and Taxpayers of Oregon City." n.d..
M.M.A. files. 
The McLoughlin Memorial Association is a private institution and the public square at the top of Singer Hill now occupied with property belonging to the McLoughlin Memorial Association is being used for private purposes.1

Dedication of the home was set for September 5, 1909, close to the anniversary of McLoughlin's death (September 3). The house was given two coats of white paint. About 500 people showed up to hear addresses eulogizing Dr. Mcloughlin, and to hear the Oregon City Band play patriotic songs. The outside of the house, now largely restored, was decorated with patriotic bunting. Among the prominent visitors attending were Frederick V. Holman, president of the Oregon Historical Society, Mrs. Eva Enery Dye, author of a book on McLoughlin, a granddaughter of ilcLoughlin, a son of the distinguished Civil War general William T. Sherman; and many early pioneers.

Mcloughlin's home was turned into a sort of "museum." People began donating items from the pioneer period. A few of the original furnishings were found but there was no real effort made to restore the house and furnish it as it was when Mcloughlin lived in it. Very little else was done with the house for many years.

\section{1} M.M.A. files.

"To the Voters and Taxpayers of Oregon City," n.d..

2

"McLoughlin is Honored," Oregen City Anterprise, 10 September 1909, clipping, M.M.A. files. 
In the carly 1930 's a renewed interest in the house was shown by the McLoughlin Memorial Association and several patriotic organizations. Architect Glenn Stanton of Portland was asked to make plans for a cómplete restoration. Along with Mrs. John Y. Richardson, chairman of the restoration committee, Stanton planned major changes in the house. Ten thousand dollars was requested from the state legislature. After the legislature appropriated $\$ 1,250$ for the house shortly following its move, the amount dwindled with each session until in 1934 the sum of $\$ 237$ was all that was 1

appropriated. Mrs. Richardson, a past regent of the

Daughters of the American Revolution and vice-president of the Mcloughlin Memorial Association, had been instrumental in getting the restoration of the house started at this time.

Work commenced on the project on Pebruary 15, 1935, as a Pederal Bmergency Relief Administration project, which employed about twenty men working in shifts of two days one week and four days the next. There were several teas given to help raise funds. The legislature provided an appropriation of $\$ 5,500$, half of what was asked for. Added to this

\section{1} clipping, M.M.A. files.

2 "Work of Improving M'Loughlin House Will Start Today." Oregen City Bnterorise, 15 February 1935, clipping, M.M.A. files. 
was another $\$ 2,250$ from private contributions. As a part of the renewed interest in the recognition of McLoughlin, the new highway between Oregon City and Portland was named after him.

It was during this period of the restoration that Barker became involved with the McLoughlin Memorial Association, joining the Board of Directors and serving on the restoration committee. Mrs. Barker also helped with the various teas given to help raise funds.

Because the house had become a repository for pioneer artifacts, Barker decided that

Our first job was to clear the house of these articles. At my suggestion a letter was written to each person on the list asking each to remove his articles as we planned to restore the building. This was a great success and practically every article was reclaimed. This done a smaller group of three was selected from the building committee to proceed with the restoration. This committee was Mrs. John Y. Richardson, chairman, Mrs. A.E. Rockey and myself. We worked with architect Glen $M$. Stanton.1

The restoration of the house was quite extensive. A new entrance was constructed, partitions were removed, fireplaces were repaired, and a new stone foundation was put in. Much work was done on the interior and exterior woodwork. The old plumbing was taken out and concealed steam radiators were put in. The yard was also landscaped. 
In a letter to Margaret Sharp, Barker mentioned

...the importance of preserving the old floors and I think it would be well to let Mr. Stanton know this. I feel very sure that this will be an issue if it is not done and we might better avoid the issue if possible. 1

Eventually this matter of the floors did become a problem between Barker and Stanton. Barker recalled,

The restoration proceeded orderly until at a committee meeting in the house with the architect we noticed that he had purchased and was preparing to lay fir flooring over the old floor. Mrs. Rockey and I protested very strenuously and told him not to do it. We being a majority of the committee thought the architect would follow our instructions. The next time we met in the house, Mr. Stanton had laid a new floor of fir over the old flooring. Things were sald to Mr. Stanton and in my office he told me that Mrs. Richardson had ordered him to proceed with the new floors regardless of the wishes of Mrs. Rockey and myself. It was then too late to take up the new floor as we had exhausted our finances. Mir. Stanton sent us a bill for $\$ 1000$. Our then treasurer, Mr. Simeon Winch, settled the bill by: giving Mr. Stanton a life membership in the Association and $\$ 500$ cash.2

In searching through Stanton's and Barker's papers, one cannot help but notice that there is no correspondence between them. Stanton apparently had dealings only with Mrs. Richardson. One letter Stanton wrote to Richardson says,

After considering the offer made by the Mcloughlin

1

Barker, Letter to Margaret Sharp, n.d., M.M.A. files. Written on bottom of letter from Margaret Sharp to Barker, 5 May 1936.

2

Barker, Autobjography, p. 150. 
Memorial Association of $\$ 500$ with a life membership as settlement in payment for our balance of $\$ 700$ we decided to accept their proposition, though we could hardly afford to for financial considerations.... We regret that one or two of the board members criticized our services to the organization and used this criticism as a justification of their request to us for a reduction in our balance. While this was not stated in fact in the letter from the president, it is our belief that it was true. However, we do not wish to have anything said about it at this time.... We are writing this in confidence and we trust that final settlement will be soon forthcoming. We only regret that an embarrassing situation had developed at the end of this very enjoyable project.1

The house was restored through the efforts of various patriotic organizations. Each group took a room for which it was responsible. They were to raise money and help with getting furnishings for the respective rooms. The National Society of Colonial Dames in Oregon took the living room; the state medical auxiliary took the office and library; the Daughters of 1812, D.A.R., Sons and Daughters of Oregon Pioneers, Daughters of Founders and Patriots, and the Portland Junior League took the bedrooms. ' Several groups were involved in other ways, such as providing the landscaping and donating the flag pole.

1

Glen Stanton, Letter to Mrs. John Y. Richardson, 8 February 1940, M.M.A. files.

2

"Work on Improving the McLoughlin House Will Start Today," Oreson City Enterorise, 15 February 1935, clipping, M.M.A. files. 
Barker and his wife were on the furnishing committee, and he was responsible for getting many of the original Mcloughlin family possessions. A particularly good stroke of luck happened when Barker found out about the Tolmie family. William Fraser Tolmie served with McLoughlin at Fort Vancouver. In 1846 Fort Vancouver closed and Tolmie went to Fort Nisqually. He took with him several pieces of furniture including the dining room table and chairs. Around 1930. Barker learned that Tolmie's son and three daughters were living near Victoria, British Columbia. They had in their possession much of the old furniture from the fort that their father took with him. Though unwilling to sell at that time, they later did sell six of the dining room chairs, with one purchased by Barker. In 1934, one of the sisters became ill and it was decided to sell some of the furniture.

Barker wrote to Miss J.W. Tolmie on June 22, 1934, ...I am writing to say that I would be willing to pay you and your sister the sum of Three Hundred and Seventy-Five Dollars (\$375.) for the six (6) chairs, the table complete with all its extensions, and the two sofas.1

The two sofas from Fort Nisqually Barker wanted to buy for his daughter. Miss Tolmie responded with a counter offer of $\$ 1,000$ for the table and three chairs. Barker responded

Barker, Letter to Miss J.W. Tolmie, 22 June 1934, M.M.A. files. 
that because the table had never been used in the house but had come from Port Vancouver he could

...find no one willing to help in this regard.... in as much as there is a table in existence in Portland which was his personal property, and used in the house, then if any effort should be made to raise money to buy any table it should be this one and not yours.... I regret exceedingly that I have found so little encouragement here among Portland people but I regret more the fact that my judgment regarding the proper table for the house has not met with approval.... However, in order to keep my selfrespect and your good will so that you may feel that I am not a mere adventurer in the matter, I am going to make you a final offer of $\$ 500$ for the entire thing, table, chairs and sofas....1

On August 18, 1934 Barker again wrote to Miss Tolmie. This time was to inform her of the plans being readied to restore and furnish the house. He mentioned that a Mcloughlin table and other furnishings had been located and that they thought the woman would sell. A few days later Miss Tolmie responded that she would accept Barker's offer of \$500. Barker wrote. "We had given up all hopes of doing anything about the matter, but having gone as far as I have I feel honor bound to go through with it." ${ }^{2}$ Barker asked her to write as much of the history as she could on each of the items which were exhibited in the house.

\section{1}

Barker, Letter to Miss J.W. Tolmie, 18 July 1934, M.M.A. files.

2

Barker, Letter to Miss J.W. Tolmie, 22 August 1934, M.M.A. Eiles. 
Barker later acquired more items from the Tolmie estate when Dr. S.F. Tolmie, the son of William F. Tolmie, and a former prime minister of British Columbia, died in 1937. The contents of his house, built by his father in 1859, were sold at public auction. Barker attended and bought many items of furniture and books as part of a pool which included Simeon R. Winch, Mary F. Failing, P.L. Jackson and John H. Smith.

Barker also followed leads which led to the discovery of many of the original furnishings. One of the most important contacts was Mrs. George Deering, a great-granddaughter of MeLoughlin. She lived in Washington D.C., and through Barker's negotiations with her she donated all her souvenirs. She also helped them locate other family members who had artifacts from the McLoughlin estate. The items she donated to the house were by far the most valuable items found. Although she had already disposed of the silver marked with the McLoughlin crest in order to help pay her brother's funeral expenses, she did donate the remaining unmarked silver, a watch which belonged to Mcloughlin, rings, crucifix, medals, and other personal items belonging to McIoughlin.

Barker seems to have been the one who advanced the idea of buying up the church property adjacent to the park

1

Barker, Autoblogrephy, p. 153. 
for the purpose of erecting a caretaker's house. Barker had hoped that the appropriation from the Federal government would be sufficient to enable them to buy the property. My thought is that the church building is old and the people probably would sell it reasonably. We could get the city council of Oregon City to vacate a dead end street between the park and the church property and in that way we could increase our property and then we could erect the guest house on the old church property and in this way have a muchly better set up.1

It was at Barker's suggestion that the rissociation inguired of the federal government about entering into a cooperative agreement and getting the house declared $a$ national historic site. Barker was well acquainted with Narold Ickes, then Secretary of the Interior. Both Barker and Ickes had attended the University of Chicago and had practiced law in Chicago at the same time. "I had a feeling that if I could get my application brought to his attention that he would look on it with favor." ${ }^{2}$

The National Park Service did look over the house and sent a report to the Secretary of the Interior. In April, 1936 the Department of the Interior ruled against the application saying

...that it did not favor the proposal because the McLoughlin House project could be handled within the files.

1 Margaret. Sharp, Letter to Barker, 5 May 1936, M.M.A. 2 Barker, Autobiography, p. 151. 
provisions of the Historic Sites Act. The problem was that the Advisory Board later ruled in the spring of 1937 that the building was only of 8 tate historical significance.1

The Advisory Board later reversed itself after Congressman John Mott gave a subcommittee of the board a tour of the house. The reason they had turned down the house was because it had been moved. After seeing the house and agreeing that it had been moved to original McLoughlin property "...they declared the house to be of national significance because of its relationship to the Westward Movement." ${ }^{2}$

On May 9, 1941, a formal contract was signed between the Mcloughlin Memorial Association, the city of Oregon City, and the National Park Service. The contract stated that neither party could make any structural changes without the other's approval. The management and control of the property remained in the hands of the Association. Either party could cancel on twelve months' notice. Barker explained this was done "so that the Federal government may not take over the management and control of the house without the consent of the Association." ${ }^{3}$ The government's

\section{1}

Charles B. Hosmer, Jr., Breservation Comes of ige, From Williamsbure to the National Irust, $1926-1949$, Vol. I. p. 696 .

2

Ibide, p. 696.

3

Barker, Autobjography, p. 151. 
responsibility was "...to give publicity to the memorial, erect a marker and to act as advisor." ${ }^{1}$ Barker, a very strong Republican, may have been mistrustful of the New Dealers getting involved in historic preservation.

This relationship between the federal government and the Association did not always work smoothly. As president of the M.M.A., Barker wrote a critical letter to O.A. Tomlinson, the regional director of the Department of the Interior. Barker was disturbed about the government accession cards and having to pay for them. Barker wrote, "...personally, I am beginning to feel that your department is doing no lifting in this matter and unless it does, I am ready to say we would better go it alone."

Barker also pointed out that the Association had invested $\$ 20,000$ already in the house and property, and that the government had not been contributing. Barker then challenged him to publish a booklet he had written on the house that would cost between $\$ 600$ and $\$ 700$ to print.

In short I want to see someone from your department show some money. If we have to raise all the funds, I am beginning to wonder what advantage there is in reporting to you. We even pay the postage in making the reports. Quite frankly, I think it is time we see some tangible interest in the form of money for the running of the house. The government is raising

1 (June 1941), p. 200 .

2

Barker, Letter to O.A. Tomlinson, 27 June 1949, M.M.A. files. 
salaries and spending billions and we are giving teas to pay our own way. I can't see it.... I urged our board to go into the agreement on the theory that some help would come out of it. That was eight years ago.1

The government did print the brochures for the Association. Its involvement today consists of printing brochures and a yearly inspection.

Barker became quite involved in his research on a cannon that had been found in the Willamette River near the confluence of the Clackamas River. The cannon was clearly marked "E.B. 1789". Barker spent considerable time researching this cannon and eventually traced the cannon to Edward Bond through the Hudson's Bay Company records. Barker was instrumental in getting the cannon placed on the grounds next to the Mcloughlin House in June, 1940.

In 1946 Barker became acquainted with Father John R. Laidlaw, the Portland Archdiocesan Archivist. St. John's Catholic Church in Oregon City had recently sold the property on which were located the graves of Dr. and Nirs. McLoughlin. Barker wrote to Father Laidlaw and said

...my decided preference is that the graves should remain where they are and a suitable memorial be erected over them. It seems to me that a Catholic shrine would be an appropriate memorial.... The

1 Barker, Letter to O.A. Tomlinson, 27 June 1949, M.M.A. files. 
locztion of your new church would be my second cholce.1

This was the last communication between Barker and the church concerning the graves for two years.

On June 19, 1948, Barker learned that a Father

Hamilton and two of his parishoners were digging for Mcloughlin's body and that of his wife. Barker telephoned Archbishop Edward D. Howard, who referred him to Pather John Laidlaw. Laidlaw told him that

...he had the consent of all the heirs to remove the bodies and that he proposed to do so. He also told me that it was mone of my concern and gave me to understand that I was meddling in something which was none of my business.2

Barker was quite upset and called his good friend Walter W.R. May, the president of the McLoughlin Memorial Association and the editor and publisher of the oregon city. Enterorise. Barker told what he had learned to May, who in turn put a reporter on the story: May reported to Barker that as best they could learn there had been no reburial. In the meantime, Barker received an anonymous phone call from a woman asking him if he "knew what was going on in

1

Barker, Letter to Pather John R. Laidlaw, 25 March 1946. M.M.A. files.

2

"Statement of Burt Brown Barker," M.M.A. files. Barker was 80 upset by what had transpired regarding the graves, he wrote a four page statement giving his version of the story. He made three copies of this and sealed it with his ring in wax. One copy went to the O.H.S., one to the

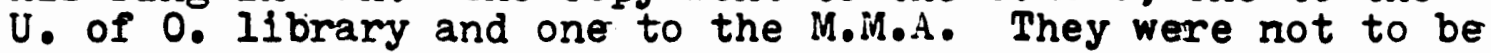
opened until one year after his death. 
Oregon City regarding the search for the body of Dr. 1

McIoughlin?" She told Barker that the body had been found, disarticulated, put in a small box, and was to be reburied quietly.

May called Father Laidlaw into his office and after two hours the priest finally admitted the story. He told May that,

They had to go down about twelve feet before they located the casket, that it was metal lined with a glass in the top over the head; that they had looked in and seen the skeleton. It was very large and in perfect condition. Due to the fact it was under the church and that it would be very difficult to take the casket out because it had isintegrated as the air struck it, they decided to disarticulate the skeleton.2

On July 6, 1948 McLoughlin and his wife were reburied on the northeast corner of Fifth and Washington streets in Oregon City, the site of the new church that was to be built. At May's suggestion Barker was selected to give the oration. He read a letter from a Hugh Burn, a pioneer who was helped by McLoughlin. In summing up his address Barker said

To those who speak figuratively it may be said that we have taken Dr. Mcloughlin from the valley of

1 Statement of Burt Brown Barker," M.M.A. files. 2 Ibide. 
despair and reintombed him in the high plateau of our esteem and affection.1

A year later May wrote to Barker concerning the remains of McLoughlin's casket. May informed Barker

The coffin, or such parts of it as they threw on the dump, was not intact when it was dumped overboard.... It would require some very serious digging that might take from a couple of days to two or three weeks....

Barker made a notation on the bottom of the letter that said,

This refers to the coffin of $\mathrm{Dr}$. McLoughlin. It was mutilated and thrown into the oregon City dump. We thought of trying to recover it but this letter indicates it would be a difficult task. We dropped the matter.2

The McLoughlins' bodies were moved once more in August 1970 , this time next to their re-located house.

Barker served as president of the Association from $1949-1950$.

I did so against my best judgment because it has been the policy of this organization, that the president should be from Oregon City. I still feel that is the proper policy, and accordingly insist that I must not again be elected your president. 3

1 "Address by Dr. Burt Brown Barker, President of the Oregon Historical Society, at the re-interment of $\mathrm{Dr}$. and Mrs. John McLoughlin, at Oregon City, July 6, 1948," M.M.A. files.

\footnotetext{
2 M.M.A. files.

Walter W.R. May, Letter to Barker, 6 July 1949,
}

3 files. Barker, "Report of the President," n.d., M.M.A. 
Barker reported that "...the principle item of interest was the visit Mrs. Barker and I made to Riviere-du-Loup and Malbaie..... 1 This was the birthplace of Mcloughlin.

From Barker's involvement with the McLoughlin House he learned a great deal. His experience with furnishing the house, serving on the restoration committee, financing, and being president all belped him in his future projects. This knowledge carried over to his work on the Minthorn House in Newberg, a tribute to his friend Herbert Hoover.

\section{1}

Barker, "Report of the President," n.d.. M.M.A. 
THE MINTHURN HUUSE, NEWBERG

The Minthorn House had been the home of Barker's longtime friend, and thirty-first president of the United States, Herbert $C$. Hoover. The two "Berts" became acquainted in Salem while attending Sunday school at the Presbyterian Church. Miss Jennie Grey, the Sunday school teacher, had a profound effect on both Barker and Hoover who admired, and more or less worshipped, her the rest of their lives. Hoover, in his memoirs, said, "At Salem a blessing came my way in the person of a lady of real understanding Miss Jennie Grey. Her interest was in boys working in stores and offices."

Hoover was born in West Branch, Iowa, in 1874, and orphaned at mine and one half years of age. He was passed around from relative to relative until in 1885 he moved west to live with his Quaker uncle and aunt, Dr. and Mrs. Henry Minthorn, in Newberg, Oregon. Dr. Minthorn was the superintendent of the Friends Pacific Academy, later known as Pacific College and now known as George Fox College. In 1888, Dr. Minthorn moved to Salem, and "began a real estate Herbert C. Hoover, The Memoirs of Herbert Hoover, Vo1. I (New York: The Macmillan Co.. 1951), p. 13. 
venture as president of the Oregon Land Co." ${ }^{1}$ Hoover worked as an office clerk for his uncle until he went off to Stanford University in 1891.

Barker used to call on Hoover at the Iand Company after they met in Miss Jennie Grey's Sunday school class. Barker later recalled that Hoover "was a modest, reticent boy of few words." ${ }^{2}$ They became good friends and frequently had dinner in the home of Miss Grey:"s father. Hoover would go out and visit Barker at his home across the river in Polk County.

In 1892 Hoover returned to Salem from Stanford University to work for his uncle during the summer. Barker remembered one Sunday afternoon Hoover came to visit him. Upon the encouragement of a family friend Barker had already decided to go to the newly formed University of Chicago, but Hoover hoped to convince him to go to Stanford.

He spent the entire afternoon but finally gave up, walked off the porch, climbed over the fence, untied his horse, got up in the buggy, took the reins in his left hand and his buggy whip in his right and turned and said to me, 'Don't go to the University of Chicago. No one goes there except preachers who eat yellow legged chickens.' Thereupon, he struck his horse with the whip and recrossed the bridge for Salem.3

1 Deborah M. Olsen, Minthorn House, (Herbert Hoover Foundation of Oregon, 1979), p. 13.

2

Barker, Autobjography, p. 35.

3

Ibide, p. 37 . 
Years later Barker became involved in restoring the Minthorn House in Newberg as a tribute to his lifelong friendship with Herbert Hoover. Whether the original idea was that of Barker or Levi Pennington is not clear. The earliest mention in the files of the Minthorn House is a letter from Pennington, then president of Pacific College, to Barker, telling him of the college's interest in the house. In this letter, Pennington said,

I remember that once when I thought we ought to get that property, you suggested some fine things in the way of fixing it up, and offered to give us $\$ 500$. on a $\$ 5,000$. proposition to buy the place, do some repairs on it, refurnish it in the style of the days when Herbert Hoover lived there, and make it a Hoover Museum, with perhaps a faculty family there to handle it.... The whole thing is on the 'quiet' thus far.1

Barker quickly responded that his offer was still good. A week later Barker wrote to Ben S. Allen, a friend of Hoover's in Palo Alto, California. He told Allen,

I have been watching this place for some years in hopes that it would come onto the market and that a few of us might get together and buy it and give it to Pacific College. I would be very willing to be one of five men to put up the $\$ 2,500$. for this purpose.

I would hate very much to see this home desecrated or destroyed as it would be a splendid memorial to be preserved.... I would be quite willing to undertake to get early Oregon furniture... if that were thought to be the proper thing to do.... I would be willing to see if we can

\section{1}

Levi Pennington, Letter to Barker, 25 June 1937. Minthorn House (M.H.) files. 
get any of the original furnishings.1

Pennington "was a busy man and never was able to pull it over." It may be that Pennington knew he would not be staying on as president of the College much longer.

Pennington was succeeded by Emmett Gulley who, after assuming his position, talked with Herbert Hoover in New York. Hoover was very modest about the idea, but indicated that he was interested in seeing the house saved as a tribute to his uncle. Gulley hoped to raise $\$ 10,000$ with which to purchase the house and restore it as a "social center for the college. ${ }^{3}$

Barker contributed the first $\$ 500$ with $\$ 4,000$ of the $\$ 10,000$ coming from Hoover's two sons. The rest came from many contributors, largely Hoover's California and eastern friends. In the meantime the purchase price of the house went up from $\$ 1,500$ to $\$ 3,500$, which the college paid in 1943. The rest of the money was turned over to the college.

\section{1} files.

Barker, Letter to Ben S. Allen, 3 July 1937, M.H.

2 M.H. files.

Barker, Letter to Edward Zimmerman, 6 November 1947.

3

Barker, Autobiegraphy, p. 178.

4 files.

Barker, Letter to Ralph Millsap, 30 June 1954, M.H. 
"Nothing more was done to the property than to allow some students to live there because of the housing shortage." For reasons which are not totally clear today conflicts arose within the administration of the college. Gulley was fired as president, and the new administration was not interested in the house. A group including Barker, Pennington, and Gulley began trying to think of what should be done. Barker wrote to Hoover's son, Allen, and told him,

We are considering the advisability of organizing a Herbert Hoover Foundation to take over the property. It is beginning to look as if the school will not be able to care for it properly.2

The College board met a month later and decided to turn over the house to the foundation. The state Republican committeewoman, Irene Gerlinger, who was present, wrote Barker that

It was a sad meeting - two donors of $\$ 4,000.00$ for the library asked for their money back, several faculty resigned, and a deficit in operating expenses was noted.3

The board not only didn't want the house, they could not afford to do anything with it at this time.

1

Barker, Letter to Bdward Zimmerman, 6 November 1947.

2 M.H. files.

Barker, Letter to Allen Hoover, 14 February 1947.

\section{3} M.H. files.

Irene Gerlinger, Letter to Barker, 15 March 1947, 
Barker always kept Herbert Hoover informed of the situation of the house. After the house was turned over to the foundation, Barker wrote to Hoover saying,

As you may have heard. Pacific College of Newberg is meta-morphacizing into something other than a iiterary college. Re-actionary forces seem to have gained control. No attention was being paid to it the hous and this concerned us. On inquiry, we learned that they had no interest and were anxious to be free of the care and maintenance.1

The board of trustees of the Poundation included, as Chairman, E.W. Gulley, friends of Herbert Hoover's. Burt Brown Barker and Mrs. Irene Gerlinger; Hoover's cousin Mrs. H Paulson; H.M. Hoskins, county judge, Mr. Frank Colcord, mayor of Newbergi and Mr. Levi Pennington, former president of Pacific College.2

The articles of incorporation for the Foundation were filed with the state of Oregon, on March 18, 1947.

A campaign was started to raise additional funds for the restoration of the house. Bert Mattei, a California friend of Hoover, agreed to raise $\$ 15.000$ for the Foundation. Barker was determined to do as complete a job as possible. "I shall not be satisfied with anything less than

1

Barker, Letter to Mr. Herbert Hoover (H.H.), 8 April 1947. M.H. files.

\section{2}

Newberg Graphic, 27 March 1947, clipping, N.H. files.

3 M.H. files.

Barker, Letter to Irene Gerlinger, 11 November 1947, 
a real memorial of which anyone can be proud." ${ }^{1}$ One of the first steps taken was to purchase a near-by house on the property which was built after the Minthorn house. They felt that it detracted from the historical interpretation of the site and should be moved. They bought the house for $\$ 8,500$ and eventually moved it two blocks south on the same street. A problem arose, in that many power lines would have to be taken down, which would be very expensive. Barker explained that the problem was solved one day when an old Quaker man walking by suggested they take the roof off the house. The movers did so and, after moving, replaced the roof, an action which saved them a considerable amount of money. They remodeled the house and sold it when the market was right.

Seeing that they were going to need more money than was originally thought, Barker set out to interest certain patriotic organizations in the project. Through the efforts of Mrs. John Y. Richardson and the State D.A.R. $\$ 500$ was given to use in furnishing the house. The Sons of the American Revolution donated $\$ 600$, and the National Society of Colonial Dames in Oregon presented \$500. Other large contributors in the early years were Hoover's two sons,

1 M.H. files.

Barker, Letter to Edward Zimmerman, 6 Pebruary 1948,

2

Barker, Autobjerraphy, pp. 178 - 179. 
Allen and Herbert Hoover, Jr., Valsek Lumber Company, and a retired carpenter who donated much of his time doing the actual work on the house. The Colonial Dames hired a firm in Salem to do the landscaping. Elizabeth Lord, daughter of former Oregon Governor William P. Lord, and Edith Shryver planned the landscaping and did much of the actual work.

A national campaign was out of the question. Hoover disliked the idea of a lot of fanfare and publicity over the restoration of his boyhood home. When Irene Gerlinger proposed that the Foundation try to promote a mational campalgn she was met by much opposition from the board and friends of Hoover. A.C. Mattei in a letter to Barker said,

I happen to know that a drive such as has been proposed by Mrs. Gerlinger would not be agreeable to him nor to the people of Newberg.... Furthermore, I know that he still is opposed to making any large national drive for funds, and for that reason it is still my opinion that we should continue as in the past, getting money where we can for this purpose without any fanfare.1

Barker had written to Mattei "The Oregon people are doing all they can but $\$ 100.00$ is a big lift for one of them. I am carrying $\$ 4,000.00$ personnally..... It was felt by those involved in the restoration that this was an Oregon project and should be left up to the people in Oregon,

\footnotetext{
1 files.

A.C. Mattei, Ietter to Barker, 23 April 1953, M.H.

'Barker, Ietter to A.C. Mattei, 23 January 1953, M.H. files.
} 
regardless of where the money came from.

This was very hard for Mrs. Gerlinger. She insisted at every board meeting to raise a national campaign to raise the money to restore the house. Mr. Hoover had his hands full trying to keep Mrs. Gerlinger from putting on a nationwide campaign to raise the money.1

Some of the money was given to the Foundation anonymously through ille. Hoover's secretary, Bernice Miller. According to the records, several large contributions totaling $\$ 15,000$ were sent between August and September, 1952. Miss Miller said, "The donors want their contribution to be strictly anonymous - - - and I don't want my name used either."

The foundation was very fortunate in the restoration of the house to have the help of two sisters who had lived in the house after Hoover did. Their father, Milton Nicholson, bought the house from Dr. Minthorn, and they remembered many of the details of the house. "Mr. Hoover gave us his best memory, which was good so far as the front and the interior was concerned, but he never could work out the back." ${ }^{3}$ The two sisters provided this information. Barker, in his autobiography commented, "Having an ingenious

1

Oral interview with Burt Brown Barker, 1962, Transcript at the 0.H.S., p. 11.

2 M.H. files.

Bernice Miller, Letter to Barker, 28 August 1952,

Barker, Autobjerraphy, p. 179. 
carpenter and two women who had grown from childhood in the house we have, I believe, a perfect restoration."

Across the alley behind the Minthorn House a home was built in the same period and style as the Minthorn House. The Foundation wanted to use it as a caretaker's house. According to Barker, "An admirer of Mr. Hoover bought it for $\$ 5,000.00$ saying he would carry it and then will it to us." This was never done. After the man died his wife offered to sell it to the Foundation for $\$ 5,000$.

This was one of the greatest blows we had faced. She had opposed her husband's purchase and had no use for Mr. Hoover and it was cash or else. There was only one course and I put up most of the money as she was very insistent. 3

The house was remodeled according to the plans of Mrs. H. Paulson. Mrs. Paulson, a cousin of Mr. Hoover, had indicated that she and her husband would like to be the caretakers of the property. Before the house was ready, her husband had a heart attack and they moved to Florida, never to return.

There was a long and intense effort to get the alley behind the Minthorn House closed. In order to do this the signatures of a majority of the property owners whose land

1

Barker, Autobieoraphy, p. 179.

2

Ibide, p. 181 .

3

Ibide, p. 181. 
was affected had to be obtained. This they were never able to do.

The Foundation also hoped to acquire the corner property north of the house which had a gasoline station on it. Shell oil Company, which owned the property, seemed willing to negotiate, but not before September 1, 1952. They needed the time to recoup their money invested in the property. The board felt there was a verbal agreement with Shell that it would give it the property.

A.C. Mattei, because of his position as president of Honolulu Oil Company, was asked to do what he could. Although Mattei had been quite successful in raising funds for the house, on this project he was not able to persuade Shell. The board was unable to do anything on its own. Barker wrote to Mrs. Gerlinger, When you see him [Mattei] fust give him to understand that we will do nothing about the service stations until he and his friends send us the 1 money." The money never came and the matter seems to have been dropped. It was finally settled in 1969, when Shell Oil Company decided not to donate the property, but to sell It for a fixed price of $\$ 10,000$. This was too much money for the Foundation to spend and the lot went to a quick-stop grocery store. This was a bitter disappointment for those

\section{1 \\ Irene Gerlinger, Letter to Barker, 11 April 1953,} M.H. files. 
who for so many yea 8 hoped to include this property as part of the restoration.

The furnishings for the Minthorn House came from many 1

different sources. Barker played a vital role, drawing from his experience in furnishing the Mcloughlin house. The Foundation was fortunate in finding some of the artifacts that were original to the Minthorns when they lived there. Barker located Hoover's bedroom furniture in the collection of the Oregon Historical Society. This furniture had been loaned to the Oregon Historical Society by a woman who had purchased it from Dr. Minthorn when he moved to Salem. It was placed on permanent loan at the Minthorn House. Other Items associated with the Minthorns were donated by: Minthorn's daughter, Mary Minthorn Strench. Dr. Minthorn's medical books were found in a basement at George Fox College, after a long search. They were taken out, dried, and placed in the house.

Barker took on this stage of the project with enthusiasm. Nöt having many original furnishings he set out to find as maay appropriate artifacts as possible. Barker was well suited for this task, coming from a similar background, and having lived in the area at the same time as hoover. His decisions were made on judgments based on his

1

For a rather complete listing of the furnishings and Where they came from see Doborah M. Olsen, The Minthorn House (Newberg, Oregonı 1979). 
memory and experiences. Through auctions, antique dealers, and private contacts Barker located stoves, rugs, chairs, and cooking utensils appropriate in their simplicity to a Quaker family of that period. The "pride and joy" for Barker was the kitchen. He took the entire responsibility "becsuse I knew less about it than any other part of the house." 1 Working alongside Barker on the furnishing of the house was his wife, Ella, and his daughter, Barbara.

From almost the start of the restoration, Barker hoped to get Hoover to come to Newberg and dedicate the house on his birthday. "It would crowd us to complete these plans for your birthday in 1950, but we aren't afraid of being crowded." Hoover declined. It would actually be several more years of hard work and planning before the house would actually be finished. Barker once again asked Hoover to come, this time on his eightieth birthday. Unfortunately, they lost out to his birthplace. West Branch, Iowa. Hoover wrote to Barker

...while I greatly appreciate this tribute of my: friends, I don't like the idea of dedicating a monument to myself. Can you not do it? You are

\section{1}

Barker, Autobjeoraphy, p. 185.

2 files.

Barker, Letter to H.H., 26 September 1949, M.H. 
my oldest living friend in Oregon (and I guess in the United States as well).1

An article in the Oregonian on August 7. 1955, said,

Dr. Burt Brown Barker found it necessary to resort to a ruse to get Mr. Hoover to Newberg for the ceremonies.... Dr. Barker learned from friends there how the coup was pulled off. It was simple, he was told. West Branch got the Iowa legislature to invite him.

So, knowing Mr. Hoover's high regard for legislative bodies, the Oregon legislature was prevailed upon to invite Bert to his own birthday party and it worked, Dr. Barker reported with a twinkle in his eyes.2

The foundation tried to get President Eisenhower and Vice-President Nixon to come also, but both declined. Everything was set for the day, August 10, 1955, the eightyfirst birthday of former President Hoover. When the day came, several thousand persons appeared, including the representatives of the television networks, to see Hoover and view the house. Hoover was introduced by the Secretary of the Interior and former governor of Uregon, Douglas McKay. Hoover's address centered on the role of the country doctor. The house was dedicated by Barker:

1. To the people of Oregon where young Hoover spent his formative days of his boyhood.

2. To the people of the United States, because Mr.

Hoover was their thirty-first president, and

3. To all the people of the world to whom Mr.

Hoover has been the greatest American benefactor.

\section{1} files.

Herbert Hoover, Letter to Barker; 31 May 1954, M.H.

2

Harold Hughes, "Newberg's Surprise for Herbert Hoover," Oregonian, 7 August 1955, pp. 4 - 5. M.H. files. 
Thus I dedicate this home to humanity with a special prayer that it may be an inspiration to youth everywhere.1

When the ceremonies were over Hoover left to go fishing for a few days. When he arrived in San Francisco, he wrote Barker to thank him for all he had done.

I do not know of any such an act of lifetime friendship and honor as you have done to me in all our long life. It is difficult to express my appreciation to you for it all.... I do not know of any man who has been given so unforgettable an occasion and reception.2

The job was not over. Having invested approximately $\$ 50,000$ in the project, the board felt that it would be best if an endowment fund was set up. Together with the admission charge the house could be maintained for many years by the Foundation without outside influence. At first they had planned on not charging admission. Some of the other historic house museums felt that this would hurt their business so the Hoover Foundation decided to charge a nominal fee.

Another reason for an endowment fund was that the board at no time ever wanted the federal government to take control of the house. This may have been because of the feeling brought on by the Democratic administrations after Hoover left office. Many of those on the board agreed with

1

Barker, Autobiocraphy, pp. 191 - 192.

2 Ibide, p. 192. 
Irene Gerlinger that "...some New Dealer would do something to be disagreeable.... I hated the New Deal with an undying hatred, particularly for what they did to smear the Chief."

Those that were involved in the restoring of this house and the raising of funds were ardent admirers of Hoover. The friends that Hoover made, he kept.

Men he had worked with since college days remained his friends until death..... Once a Hoover man, they said, always a Hoover man. A telephone call from him would send them flying across the nation or the world. In exchange his home and his heart were open to them.2

Barker was one of those. Many times Hoover asked him to see that addresses he was about to give were broadcast from Portland. Barker was always happy to do what he could.

After the house was dedicated the drive for an endowment grew. In August, 1957, the Foundation had between four and five thousand dollars. By July, 1959, they had raised this to about $\$ 7,500$, and were hoping to have $\$ 25,000$. In 1962, they received a couple of large contributions. One was from Pendleton Woolen Mills for $\$ 2,500$, and an equal amount came from Clarence Bishop, a good friend of Barker's and president of Pendleton Woolen Mills. In a 1963 letter to C.H. Watzek, Barker said his daughter was going to visit

\section{1}

Irene Gerlinger, Letter to A.C. Mattei, 25 April 1953. M.H. files.

2

Gerre Sinith, The Shatteread Dream (New York: William Morrow and Co.., Inc., 1970), p. 237 . 
Hoover and

How I would love to see his eyes open when she tells him we already have an endowment of $\$ 25,000$ and going strong. It will be a glorious surprise for I have mever told him about it. I want him to be surprised.1

Dr. Barker convinced several admirers of Hoover: to leave bequests in their wills to the Foundation.

In 1965. Barker proclaimed, "Our income from the endowment plus the gate receipts cover all the expenses, so we are not passing the hat." ${ }^{2}$ The net worth of the Foundation in 1967, was listed at over $\$ 77,000$, with $\$ 30,000$ in real property, over $\$ 40,000$ in securities, with the balance in the checking and savings. The value of the furniture in the house was included.

The name of the Foundation was changed in 1966, from the Herbert Hoover Foundation to the Herbert Hoover Foundation of Oregon. This was done at the request of Allen Hoover because of conflicts with the foundation administering the Hoover birthplace in West Branch, Iowa. The board unanimously agreed to the change.

\section{1} files.

Barker, Letter to C.H. Watzek, 8 January 1963, M.H.

2 M.H. files.

Barker, Letter to Herbert Hoover, Jr., 9 March 1965, 3 "Pinancial Statement," 1967, M.H. files. 
Barker's intentions were to make the Minthorn House the best financed historic house museum in Oregon. Barker also made arrangements to have his work carried on after his death. His daughter Barbara was elected vice-president. In a letter to Mr. Hoover, Barker said,
I am very proud of Barbara.... I feel very secure to have her pick up where I let go when the bell tolls, and she has two sons and a grandson who will carry on after her, so you can see I have a hierarchy set up to care for the house for at least two generations. I think we can outlast the Kennedy dynasty if it doesn't bankrupt us.1

Barker's daughter, now Mrs. John Sprouse, has carried on the work started by her father since his death, serving as president of the Foundation. In October 1981, ownership of the house was transferred to the National Society of Colonial Dames in Oregon. "The house...was becoming difficult to maintain as those interested in its preservation grew older...."

Barker, in his many years devoted to this project, was driven by a strong sense of patriotic duty, civic and state pride, and most importantly, his sincere admiration for Herbert Hoover. Because Barker enjoyed a certain amount of financial independence, he was able to spend the time necessary to work on the project. He also had many influential

1

Banker, Letter to H.H., 21 February 1963, M.H. files. 2 Blizabeth Harney, "Hoover Boyhood Home Ownership to Change," Oregonian, 8 October 1981, Sec. B, p. 2, cols. 1 2. 
friends who were always willing to listen and to assist. Besides restoring the house, Barker had it listed on the National Register, had appropriate signing placed for the house, convinced the state to name a portion of the highway from Portland to Newberg the "Herbert Hoover Niemorial Highway", and was instrumental in establishing "Hoover Park", across the street from the Minthorn House, which was dedicated August 10, 1955. 


\section{CHHPTER V}

\section{FORT CIATSUP, ASTURIA}

Fort Clatsop, the site of the Lewis and Clark winter camp near Astoria, is the only National Memorial Park in Oregon. Within the boundaries of this park, the Lewis and Clark party spent the winter of $1805-1806$, where they built a primitive shelter of logs. It was in 1948 while Barker was president of the Oregon Historical Society that this site was excavated.

The Lewis and Clark expedition was significant because it helped open up the land west of the Rocky Mountains and, later, helped the United States in its territorial claim against England to land in the Pacific Northwest. Lewis and Clark were only too happy. to leave Fort Clatsop in the spring of 1806 .

Through a dismal wet winter Clark counted only six days of sunshine between January and the last week of March, the men hunted, suffered winter colds, food poisoning, and petty accidents, and counted the days until they could go home. Lewis and Clark worked over their maps and notes, talked with the Indians about their lives and customs, and the local topography, and planned the expedition's return route.1

1 Dorothy 0. Johansen, Bmpire of the Columbia, p. 78. 
After the fort was abandoned it quickly began to disappear due to the climate and the dense vegetation of the region.

is early as 1813. seven years after the Fort had been abandoned by Lewis and Clark, Alexander Henry wrote that he had visited the site and that the quarters '...were in total ruin..... 1

The foundation of the fort was still visible in the early $1850^{\circ} \mathrm{s}$, but by the $1870^{\circ} \mathrm{s}$ all traces of the fort had disappeared.

The site had been known for many years. The Oregon Historical Society first identified the site jn 1900, and in 1901 purchased three acres. An additional three acres were purchased in 1928. A marker had been placed at the location, but other than that nothing had been done.

Barker became involved with the Fort Clatsop site through his work with the Oregon Historical Society. He joined the Society in the middle $1930^{\circ} \mathrm{s}$, and was elected to the Board in 1939. The Society at that time "...was not very active. Few persons were interested and the youth and vigor of its founding and early days had grown dim." Barker became secretary of the Society in March 1946, a term which lasted until December 1947, when he was elected President.

1 "Fort Clatsop Site," O.H.S., Mss. 212. 2 Barker, Autobjography, p. 200. 
During Barker's term as President, Iouis R. Cayfield, an archeologist for the National Park Service, excavated the site in 1948. Cayfield was able to locate five fire holes, along with evidence of charcoal and animal bones. Barker visited the site to see firsthand the evidence found. "We were anxious to establish the location for we had in mind a possible celebration of the sesquicentennial celebration in 1955." Cayfield concluded from the evidence that "...it can be safely stated that the excavation was done on the Lewis and Clark site at Fort Clatsop."

In anticipation of the upcoming celebrition, the citizens of Astoria became interested in taking a part. Iancaster Pollard, director of the Oregon Historical Society, wrote,

You cannot possibly imagine how delighted we are that the Junior Chamber of Commerce of Astoria is planning to look after the site of Fort Clatsop. That property has been an eyesore to Oregon since, as far as I know, the Lewis and Clark Expedition started back to $S t$. Louis. 3

On February 1, 1954, Governor Paul I. Patterson named Barker chairman of the Sesquicentemial Committee. The

\section{1}

Barker, Autobjography, p. 200.

2

Louis R. Cayfield, "The Exploratory Excavation of Fort Clatsop," Orecon Historical Quarterly, XIIX, no. 3, (1948), p. 209.

3

Lancaster Pollard, Letter to Charles E. Lauderdale, 14 October 1953, O.H.S., Mss. 212. 
...other members of the committee weres

Iancaster Pollard, Dr. W.I. May and Mrs. Kelsi

Osborne. All were residents of Portland except Dr. May, who lived in Astoria, Oregon.1

The plan was to coordinate with other states through which

Lewis and Clark passed, to put together local celebrations.

No funds were being appropriated by the different states.

In May, representatives from Oregon, Idaho, Montana,

North Dakota, and South Dakota met in Helena, Montana.

Plans were made to try: and interest Nebraska and Missouri in the celebration. It was also decided to get the Boy Scouts involved. In July Barker wrote a letter to President Dwight

D. Eisenhower

...suggesting that he issue a proclamation to commemorate the Lewis and Clark Expedition of 1804 1806. I got Governor Patterson to follow up this request by a similar one addressed to President Dwight D. Eisenhower. A commemorative U.S. stamp was issued and offered for sale on July 28.... We did succeed in getting President Eisenhower to issue a proclamation dated July 27. 1954. This was later followed by proclamations by the governors of the other western states.2

Lancaster Pollard resigned as director of the Oregon Historical Society in 1954 and Thomas Vaughan was chosen as his successor. Vaughan, Mrs. Osborne, and Barker all went to Astoria and

...enlisted the interest of the Junior Chamber of Commerce to undertake the task of clearing the Fort clatsop site and securing the consent of the Crown

1

Barker, Autobiegraphy, p. 203.

2

Ibide, p. 203 . 
Zellerbach Paper Company to select and furnish the logs necessary to reconstruct Fort Clatsop according to data in the minutes of the expedition.1

The plans were based on a sketch made by Rolf Klep, a technical illustrator in New York who had been raised in Astoria.

Clatsop County contributed $\$ 1,000$ to the project. Barker, on January 3, 1955, "...wrote a long letter to the Weyerhauser Timber Co. asking for a minimum contribution of $\$ 5000$. The response was a check for $\$ 250 . "{ }^{2}$ Governor Patterson made an effort to get a $\$ 25,000$ appropriation. "All he was able to accomplish was to get an extra allowance on his expense budget of $\$ 3000.0^{3}$ The Crown Zellerbach Company did provide the logs for the reconstruction of the fort.

I have forgotten the number of logs required but it was a large number and in the end an expensive undertaking. All logs had to be brought from wherever they were found throughout their forests and delivered to the campsite. Here the Fort had to be correctly reconstructed from logs of the correct dimension and length. This meant that the Chamber had to provide a logger and assistants who could notch the logs properly and then lay them up the same as they lay when the Fort was finally reconstructed.... This having been done the entire Fort had to be torn down, each $\log$ numbered and all logs then taken back to the company plant and wolmanized. This was a bath to preserve the wood.

1 Barker, Autobiegraphy, p. 204.

2 Ibide, p. 204.

3

Ibide, p. 207. 
This having been done all the logs had to be taken again to the campsite and again the entire Fort had to be reconstructed.1

The Junior Chamber of Commerce hired men who did the cutting and reconstruction of the Fort. Some members also contributed many days as helpers on the project. "The Fort had been very well reconstructed, the immediate location had been cleared and ample parking space provided."

The overall plan for the celebration of the Sesquicentennial called for each state to synchronize their events so there would be a continuous series from start to finish.

The plan was never organized.... Une vital element was missing - - namely no legislature in any state provided necessary funds. Another element was that the plan was not put into motion in time. 3

Barker credits Crown Zellerbach Company for the success Oregon showed in getting the project and celebration going

... and yet it was a struggle to accomplish what we did, and that could not have been done without the valiant voluntary effort of the Crown Zellerbach Company at an estimated expense of $\$ 20,000$. I am quite frank to say that this company saved the day and made the celebration a success. 4

1

Barker, Autobiography, pp. $204-205$.

2

Ibide, p. 206.

3

Ibide, p. 205.

4

Ibide, p. 205. 
The dedication of the Fort took place on August 21, 1955. The main speaker was Douglas McKay, Secretary of the Interior and former Oregon governor. Uther speakers were the governors of Oregon and Washington, the mayor of Astoria, and representatives from the Senior and Junior Chamber of Commerce. The Boy Scouts attended. Barker spoke for about fifteen minutes pointing out the historical importance of the Lewis and Clark expedition. Barker accepted the fort as president of the Oregon Historical Society. He ended his speech with,

We wish to preserve this Fort as a symbol of what free men acting under a free government are willing to sacrifice and to suffer for future generations. Our earnest prayer is that

These grounds

Consecrated by cenerations of the past, May not be

Desecrated by generations of the future. 1

The question of who was to be responsible for the property was the next issue to be discussed. The Oregon Historical Society owned the land, but the Junior Chamber of Commerce was promoting the project. According to Barker,

It was a real undertaking and in the end they saw that much more labor would be required to care for and protect the Fort. This we had anticipated. The reconstructed Port was on land which had for many years belonged to the Oregon Historical Society. One of its duties was to acquire and care for historic sites such as Fort Clatsop.2

1

Barker, Autobiography, p. 206.

2 Ibje. p. 205. 
The plan was to have Fort Clatsop created into a National Park.

Historically we faced a federal roadblock because there had been a previous effort in 1937 to make it a Federal project which was considered by the Advisory Board on National Parks, Historic Sites, Buildings and Monuments. The result of that study was that the Board turned it down as a Federal project and advised it be made a state project.1

Barker felt that they had an advantage because of the Secretary of the Interior McKay's Oregon connection. Also with Senator Richard I. Neuberger's interest in Oregon history he felt "...that with this much influence in Washington we stood a good chance of interesting the Federal Government....we felt the effort was well worth while."

On July 12, 1955 Senator Neuberger introduced a bill,

To provide that the Secretary of the Interior shall investigate and report to the Congress as to the advisability of establishing Fort Clatsop. Oregon, as a national monument. 3

Barker was asked by Senator Neuberger to write a letter pointing out the significance of Fort Clatsop. This letter was entered into the Congressional Record on February 26. 1958.

1

Barker, Autobioeraphy, Appendix, Letter to C.I. Peterson, 26 July 1963.

2

Ibide, p. 208.

3

Ibide. p. 209. 
A second dig had been started in December 1956 by Paul J.F. Schumacher, archeologist for the Department of the Interior. During the winter it was not known if there would be funds to do further digging. The idea of using volunteers was suggested. At this time Thomas Vaughan wrote Dorr G. Yeager, Regional Chief of Interpretation for the National Park Service :

We should very much like to have Mr. Schumacher return to Astoria and conduct further examination of the grounds.... The Society feels that Mr. Schumacher did a fine job on the dig, but may $I$, in strictest confidence, suggest that people in the area are somewhat intractable. They are unusually enthusiastic but not always susceptible to professional suggestions! in consequence, tact must always be the first consideration.1

A second archeological project at Fort Clatsop was funded by the National Park Service, and in April 1957

Schumacher returned to Astoria. He reported

Not having uncovered the positive evidence of proof we were seeking from an archeological standpoint, we are able to turn over to the historians merely two points of interest, the approximate location of a mid to late 19th century occupation site... and the location of a quantity of campfires, each one of considerable duration, containing no artifacts to date them. It remains for the historians to evaluate the evidence relating to these two locations, along with the documentary sources, to see if it throws any significant light upon the history of Fort Clatsop.2

1

Thomas Vaughan, Letter to Dorr G. Yeager, 5 March 1957, O.H.S., Mss. 212 .

2

Paul J.F. Schumacher, "Archeological Field Notes, Fort Clatsop, Astoria, Oregon," 22 January 1957, revised 28 May 1957, O.H.S., Mss. 212, p. 19. 
During the negotiations with the Department of the Interior over the proposed National Park status for Fort Clatsop a question of whether this was the actual site of Lewis and Clark's campsite arose. Due to the fact that the archeologists had not found convincing evidence there were those who were not in favor of the Federal Government taking over control of the park. This was discussed in a letter from Thomas Vaughan to Senator Neuberger.

I still feel the National Park Service is being cautious to the point of absurdity in regard to this matter. The examples they use to support this cautious approach are, in my estimation, in no way similar to the Fort Clatsop project.1

In defense of the site the oregonian came out in its editorial on May 25, 1958 saying,

...the validity of the location has been questioned by excavators who seem to expect to uncover something like the Parthenon on the bank of the Lewis and Clark River. Although their spades turned up clear evidence of fire pits, the archeologists shook their heads and muttered about the need to discover buttons, or buckles or pottery. Thomas Vaughan, director of the Oregon Historical Society, explained logically that such objects had been quickly appropriated by: Indians. But the exasperating doubts continued to exist in some parts of the Federal bureaucracy, even after a countywide civic undertaking succeeded in completing a replica of the $1805-6$ fort on the society's property.2

\section{1}

Thomas Vaughan, Ietter to Senator Richard I. Neuberger, 7 June 1957, O.H.S., Mss. 212.

2

"Fort Clatsop Triumph," Bditorial, Oregonian, 25 May 1958, clipping. O.H.S.. Mss. 212. 
Senate Bill S. 3087 was signed by President. Eisenhower on May 29, 1958 after the House Bill H.R. 10120 had passed nine days earlier. This

\begin{abstract}
...final bill called for the Oregon Historical Society to pass title to the land it had owned for many years, and in addition the Federal Government was to acquire in excess of 100 additional acres. The Act was finally passed on March 31,1958 and was to be known as the Fort Clatsop National Memorial. Suitable Museum and other buildings were to be established at an estimated cost of $\$ 276,000$ and subsequently carried on under the direction of the National Park Service as a National Memorial Park.1
\end{abstract}

The dedication of Fort Clatsop National Memorial Park was delayed because of the death of Serator Neuberger in March 1960. In his place Maurine Neuberger was appointed Senator. She had worked closely with her husband on the Fort Clatsop bill. The park was opened to the public January 1, 1963. The formal dedication was set for Sunday, August 25, 1963.

Instead of an open meeting at the Fort, it became necessary to hold the exercises in the High School. The principal speaker was Conrad I. Wirth, Director of National Park Services, Department of the Interior. He was introduced by Mrs. Richard Neuberger, who had succeeded her husband as the Senator from Oregon.2

Barker credits Senator Richard Neuberger with getting the fort recognized by the Federal Government. In my opinion this Fort Clatsop National Memorial

1 Barker, Autobiegraphy, p. 208. 2 Ibide, p. 213. 
Bill will live as one of the most lasting pieces of federal legislation accomplished by Senator Neuberger. It was long overdue. The Oregon Historical Society had made several efforts to get the Oregon delegation in Congress to try to get the Fort put under federal control, but never succeeded until Senator Neuberger saw the vision and began in 1955 a long and careful approach to the subject. It is to be regretted that he did not live to be the leading spirit at the dedication.1

Barker was on hand at the dedication to see the completion of the project he helped initiate. He had been instrumental in getting the fort reconstructed, which led ultimately to the Fort Clatsop National Niemorial. 


\section{CHMPTER VI}

\section{OX BARN MUSEUM, AURORA}

Today in Aurora visitors curious enough to inquire will be told a rather unusual history. They will hear stories about a man named William Keil, and how he brought his dead son to Oregon from Missouri in a lead-lined coffin filled with alcohol. Undoubtedly mentioned will be the craftsmen, farmers, and musicians who were members of this unique community, similar to the one Keil started earlier in Bethel, Missouri. Artifacts from the Aurora Colony are on exhibit at the $0 x$ Barn Museum, near the center of town. On the outside of the building there is a plaque stating that the building is dedicated to Burt Brown Barker, "Historian, Author, Scholar, Great and Good Friend of the Oregon Country."

The Aurora Colony was a German religious communal society founded by Dr. William Keil in 1856. Dr. Keil started the colony earlier in Bethel, Missouri in 1844. Some of these people had been members of the Harmony Colony in Pennsylvania. The Bethel Colony was successful, but Keil decided to leave with part of that group in 1855 to go to the Oregon Country.

He removed from Missouri to Oregon because he imagined that there would be a larger field for his 
efforts in a new state and also. I imagine, because of an innate restlessness of disposition.1

Malaria and threat of a civil war may have: also influenced his decision. This was the first communal society to migrate to the West, bringing a tradition of communal living that first started in America with the Mennonites during colonial time.

Keil promised his nineteen-year-old son Willie that he could lead the wagons to Oregon. The son died shortly before they were to leave. His father kept his promise by preserving him in a lead-lined coffin filled with alcohol. Six months later, Willie was buried at the scout-chosen site close to Willapa Bay, near the present day town of Raymond, Washington. Keil felt that area was too isolated, wet, and infertile, however, so he went to Portland. The next year a spot was selected and land purchased, about twenty-five miles south of Portland, along the Pudding River.

The Aurora Colony grew and prospered. At its height in the late $1860^{\prime} \mathrm{s}$ the Colony numbered almost 600 people. They worked hard and gradually they were able to acquire over 18,000 acres. The town included a fine hotel and restaurant. The good food prompted Judge Matthew P. Deady

1

Charles Nordhoff. The Communistic Societies of the United States: From Personal Observations (New York 8 Dover Publications, Inc , 1966, reprint from 1875 ed., New York: Harper \& Brothers). p. 306. 
to comment in his diary, "I wish there were a Dutchtown at every station in Oregon."

A copy of the post offic application, dated September 24, 1857, states, "Aurora Mills comprises 1 storehouse, 1 tavern, 1 sawmill, 1 gristmill, 1 blacksmith shop, farm houses, with sixty inhabitants." Later Aurora would include a school, church, hotel, general store, spinning mill, and furniture shop. The town also boasted a fine park and a very popular band. The music teacher was Henry $C$. Pinck.

At Aurora he organised and traimed two bands and several orchestras. The bands and the orchestras and the community singing made the colony famous throughout the West. The bands were in demand for celebrations and political and other meetings all over the coast. They furnished the music for the Oregon State Fair at Salem. As before said, every Aurora funeral had band music, and they played antiphonal pieces from the two balconies of the Aurora church on festival occasions and holidays. Railroad excursions from Portland and elsewhere were welcomed by the bands. 3

The community centered around the personality and ideas of Dr. Keil. He was a charismatic person who was the leader and also the preacher for the group. Keil based his

1

Malcolm Clark Jr., Pharisee Among Philistinese The Diary of Judge Matthew P. Deady 1871 - 1892 (0.H.S., 1975), p. 159.

2

Post Office Application, 24 September 1852, Aurora Colony Historical Society (A.C.H.S.) files.

3

Robert J. Hendricks, Bethel and Aurora (New York: Press of the Pioneers, 1933), p. 161. 
philosophy on the Bible. He preached the "Golden Rule", brotherly love, and a sharing of goods. Keil was the absolute leader in all matters. It was for this reason that with Keil's death in 1877 the Colonists disbanded and the property was divided among the members. Because two states were involved, the division of the property was disbursed through the federal courts with the last legal document signed in 1883. The settlement was such that no lawsuits were involved. Many of the colonists stayed in the furora area on land given them.

Bxcept for Dr. Keil's house which burned down in 1903, and the colony church which was torn down in 1911, Aurora remained relatively unchanged until the depression in the $1930^{\circ} \mathrm{s}$. The town underwent several changes at this time. The Colony members were dying out, although descendants remained. The two banks in towr and the loan company failed. Many of the young people went off to find jobs in the cities. The school districts had been joined in the $1920^{\prime} \mathrm{s}$, which resulted in the children from Aurora going to school in Canby. Most devestating of all to the town's buildings was the construction of highway 99E. When it was completed, the town was bisected, with the result that several of the old colony buildings were moved, chopped off, or torn down. The most important building razed at this time was the old Colony Hotel. The street system in Aurora was changed. 
The population of the town did not grow for many years. One newpaper reporter called Aurora, "The Town of Empty Windows." 1 The next major event to take place in Aurora, one which would have a direct impact on its future, was the 1956 centennial. The town exerted itself in promoting its historic beginning. The celebration lasted three days. There were free barbeque sandwiches, a play depicting the 1855 migration, and a queen, Mrs. Amy Will Hurst. The men grow beards and the ladies dressed up in bonnets and long skirts. Many of the descendants went to their attics and brought out old relics from the colony to wear and display.

It was from the spirit of this centennial celebration that the people first awakened to the fact that their town's history was unique and worth preserving. Ifttle was done until 1960 when Robert Bogue, Portland State College development officer and coordinator of P.S.C. Peace Corps special programs, was driving along an unfamiliar road near iurora and saw an old house. He stopped and investigated, and became interested. Checking into it he found that the house had been built in 1860 for Frederick Keil, a son of Dr. Keil, and it was for sale.

\section{1} Carl Gohs, "The Town of Empty Windows," n.d., clipping, A.C.H.S. files.

2 Iucille Bogue, Colony House in Aurore (n.p., 1965), A.C.H.S. files. 
It was through the enthusiasm of Robert and Iucille Bogue for restoring this house that the restoration movement in Aurora began. Others had been interested in the house earlier, including Ruth Powers of Oregon City. She has been active in mumerous restoration projects in Oregon. Several years earlier, Powers had written to Barker, "When I complete my term as State Regent D.A.R., I hope we may work together to preserve the Kiel (sic) House as well as the Parsonage." Barker at the time was fust finishing his work on the Minthorn House and was involved with trying to find a home for the Parsonage.

The Bogues went ahead restoring the house, with many members from the community pitching in. Bogue credited Barker, "...with revealing the historical significance of the place - that it was not just an old house." ${ }^{2}$ Through the Bogues' effort, interest was renewed in the town's buildings and history. They helped the community to estabIish the Aurora Colony Historical Society.

The first meeting to discuss the proposed historical society was held on June 27, 1963.

\section{1} files.

Ruth Powers, Ietter to Barker, 17 June 1955, M.H.

2

Alfred C. Jones, n.d., clipping, A.C.H.S. files.

3 files.

"Minutes of the Meeting," 27 June 1963, A.C.H.S. 
A motion was made by Lester Peter and seconded by Robert Bogue that we organize a Historical Society. The motion was unanimously accepted by the 19 persons present.1

Wayne Yoder, a local onion farmer, was elected the first president, and a committee was established to write the bylaws. A motion for $\$ 1.00$ per year membership dues was passed.

The next meeting, two weeks later, over forty persons attended. At this meeting Bogue proposed,

...the possibility of opening the old Keil House... to the public for admission during the month of August.... It was suggested that perhaps the Historical society might be interested in sponsoring the exhibit of the Keil House as the special annual event of the Society.2

A committee was formed to plan such an event. The house was opened from August 4 th to September 30 th and was well received.

In September the Board of Directors met and

Discussion was held on the possibility of acquiring a building in Aurora where a permanent exhibit could be displayed by the Historical Society. Buildings discussed were the old ox barn, the kraus house, the present hotel building, the funeral parlor, and the wirth store.3 files. "Minutes of the Meeting," 27 June 1963, A.C.H.S.
2"Minutes of the Meeting," 11 June 1963, A.C.H.S.
files.

1 files. "Minutes of the Meeting," 27 June 1963, A.C.H.S.
"2 "Minutes of the Meeting," 11 June 1963, A.C.H.S.
files. ${ }^{3}$ "Minutes of the Board," 11 September 1963, A.C.H.S.
files. 
At the membership meeting on September 19th, a committee was formed to investigate possible building sites.

At the next meeting of the Society in October,

Mrs. Bogue informed the directors and committee members that a group of friends of Dr. Burt Barker are interested in doing something as a tribute to Dr. Barker in honor of his birthday in November. These people would like to donate money to the historical society to be used in the purchase of the ox barn as a tribute to Dr. Barker.... If the historical society will go along with this and manage it, the donors will have nothing to do with the operation. The price of the building has been set at $\$ 3500$ and this sum of money has been promised by the Portland group.1

This group included Barker's daughter, Mirs. John Sprouse.

It was decided to meet the following Saturday to examine the building and get an estimate of the cost of its restoration. it the board meeting on November 1, the committee reported that an experienced construction worker examined the building and found it quite solid. A series of drawings were made showing how the building could be used as a museum. "It was thought the museum could become selfsustaining in a few years." 2 The motion was made and passed to recommend the offer be accepted by the historical society to restore the ox barn.

\footnotetext{
1 "Minutes of the Board," 17 October 1963, A.C.H.S. files. "Minutes of the Board," 1 November 1963, A.C.H.S. files.
} 
Preceeding the membership meeting on November 21 Ruth Powers presented a check for $\$ 3,500$ to the historical society to be used to purchase the ox barn.

The fund-raising campaign promoted by Mrs. Powers was responded to by the many friends of Dr. Barker who have known him to be long dedicated to the preservation of our American Heritage. Dr. Barker accepted the key to the ox barn from Mrs. Amy Hurst, who grew up in the building which at one time housed the store of her father, Frederick Will. Dr. Barker then spoke to the group. He expressed $h$ is interest in the preservation of such historical sites and noted the spirit and eagerness of the Aurora community to restore the colony building and to create a museum.1

At the same metting, Ruth Powers was asked her ideas regarding the restoration of the ox barn.

She suggested that we begin with the roof and foundation of the building. She felt the building should remain as it was originally. Any departure from the original structure was believed by Mrs. Powers to change its purpose.2

Restoration of the building proceeded slowly with volunteers working on Saturdays. The first thing done was to replace the floor. The roof, it was decided, could be patched and fixed and, in the future, replaced. Robert Bogue arranged for a group of thirty Peace Corps workers to help paint the building.

People were interested in donating items to the museum, but they were concerned because no one was there to

1 files.

"Minutes of the Meeting," 21 November 1963, A.C. I..S.

Ibide 
guard them. Colony descendant Grover Giesy was contacted and agreed to live in the building, rent-free, for the period of restoration, and to help with odd jobs.

At the membership meeting on February 18, 1965, the layout chairman Lester Peters submitted his report.

He stated the committee had met and recommended the large room be converted into an old fashioned store, and the smaller room downstairs to be made into a kitchen, the upstairs to be converted into compartments and each compartment to have a display of various crefts that pertained to the colony, such as weaving, basket making, leather goods, blacksmithing, pictures and music as well as many others.1

The small room downstairs was developed into an exhibit and meeting room. The annex adjoining this room was made into a modern kitchen. A large wash house fireplace was reconstructed in this room. Also placed in this room were many kitchen artifacts including dough boxes, pie coolers, and small kitchen utensils. Today it is known as the Society room and the meetings are still held in it.

At the same meeting it was decided to receive artifacts on Saturday and Sunday February 20 and 21. At the next meeting it was reported that the "...items for the museum were not being brought in as expected." ${ }^{2}$ Another date was set, Sunday March 21. It appears that things did files.

1

"Minutes of the Meeting." 18 February 1965, A.C.H.S.

2 files.

"Minutes of the Meeting," 18 March 1965, A.C.H.S. 
start to come in, as is evidenced by the minutes of the board meeting on May 4. "The floor downstairs should be sanded and cleaned up and the old furniture refinished." The question of refinishing the furniture came up again several months later.

Mrs. Sprouse talked about the refinishing of the furniture and wondered whether retired people or the extension club would be interested in helping under the supervision of some competent person..... However, a big question was as to whether the colony furniture was painted or kept natural color.2

Some furniture was refinished in spite of the fact it had been originally painted.

Mrs. Bogue, whose husband had died in December 1964, announced in May that she was going to open the Keil house in June, July, and August, and all donations received would be given to the muserm. The Aurora Women's Club made donations and $\$ 500$ was received from the Davis Memorial Foundation. In April 1965, the first annual Sausage Dinner was held and was very successful.

The Society seems to have examined several possibilities about how the building was going to be converted to a museum structure. In July 1965.

Bruce Giesy read a letter from Mrs. Powers advising him that Mrs. Sprouse, daughter of Dr. Burt Brown

1 "Minutes of Special Board Meeting," 4 May 1965. A.C.H.S. Piles.

\section{2}

"Minutes of Special Board Meeting," 17 February 1966, A.C.H.S. files. 
Barker had employed the service of an architect and was making plans to help restore the museum as a tribute to her father and would advise the Board of Directors at a later date of their plans.1

The architect she employed was George McMlath, of Portland, who had also worked on the Parsonage in Salem.

At the next meeting Barker and his daughter both attended and brought with them the plans

... which were enthusiastically received....

It was then moved by Mrs. Powers and seconded by

Bruce Giesy that the preliminary plans be accepted by the board with a special thanks to ilrs. Sprouse. Motion carried.2

A special meeting of the membership was held on September 30 at which the plans were presented. Again they were enthusiastically accepted. "Some of the matters discussed were the building of rest rooms, fireplaces, doors and windows, fire extinguishers and finishing the roof." 3 The plans also included a large wagon shed to be constructed in back of the Ox Barn.

The plan that finally emerged consisted of remodeling of the old ox barn. Little serious consideration was given to returning the building to its original barn-like files.

1 "Minutes of the Meeting," 18 July 1965, A.C.H.S.

2

"Minutes of Special Board Meeting," 20 September 1965. A.C.H.S. files.

3

"Minutes of Special Membership Meeting," 30 September 1965. A.C.H.S. files. 
appearance. This would have meant no floors, windows, fireplaces or additions. What emerged from the months of discussions was a building where meetings could be held, a modern kitchen for the groups using the facilities, bathrooms, and a room for exhibits. By using the present windows and installing additional ones, the building took on the appearance of what it looked like around the turn of the century, when it was the Fred Will general store.

In May 1966, Barker donated $\$ 906$ for the purchase of thirty feet of additional land, south of the museum property, from the Johnson estate, better known as the Antonia Kraus Estate.

Dr. Barker spoke and explained that he purchased the additional land from the Johnson Estate to keep the museum corner free from any commercial building. Dr. Barker and Mrs. Sprouse also spoke about Aurora Colony things being sold to collectors which should rightfully come to the museum. They again stated that they would like to see more interest from the Aurora community in establishing this museum.1

The firet meeting of the Historical Society held in the Ox Barn was on July 21, 1966. Before this they met in the Keil house, fire hall, and the basement of the Presbyterian Church. It was announced at this meeting that Barker had donated another $\$ 1,000$ to the Society. Barker spoke at this meeting about the research he had been doing on Aurora's history. He tried to distinguish Aurora's

\footnotetext{
1 files.

1 "Minutes of the Meeting," 19 May 1966, A.C.H.S.
} 
communalism from Marxian communism:

... in his careful research he found it was a great error to use the word 'communist' as the whole Colony was based on a 'cooperative' and this must be stressed by all, and especially in all publications. 1

The Aurora Colony was a communal or cooperative society, certainly different from most forms of modern communism. The communism as practiced by those in Aurora was a true biblical version, based on the Bible passage in the Book of Acts 2844 - 45, which says "all that believed - - had all things common." The members of the Aurora Colony owned all land and goods in common. Their philosophy held that one should not waste anything and should all live together, though in separate homes.

At the July meeting the date for the dedication was set for September 25, 1966. During the September 15 meeting. Barker brought up the idea of obtaining the old colony church bells for the occasion. There were three bells: the smallest was in the possession of Hugo Keil, the largest was owned by the City of Aurora, and the third bell was in the Wilsonville United Methodist Church, also known as the "Frog Pond" Church. The first two bells were available, but the bell in the church was not. Its congregation felt that the bell had been placed in their church when it was dedicated and that they had a justified claim to keeping files. "Minutes of the Meeting," 21 July 1966, A.C.H.S.

1 files. "Minutes of the Meeting," 21 July 1966, A.C.H.S. 
It there. Two of the three bells eventually were moved to the museum in 1980.

The dedication of the Ox Barn Museum took place on September 25, 1966, as planned. Governor Mark Hatfield was invited and attended. Barker, in his address, stressed that:

The restoration and development of this $0 x$ Barn is an effort to correct a misrepresentation of the spirit of the Aurora Colony and to give it its proper setting and perspective in early Oregon History. It was different from every other community in Oregon and this difference has been the basis of a false interpretation by our early pioneers, and has 80 overshadowed the true story of the colony that we hope the Ox Barn may be the medium through which the proper worth of the colony may be established.1

The rest of Barker's dedication speech was devoted to outlining the Aurora Colony's achievements in music and craftmanship. In conclusion Barker said.

The $0 x$ Farn is to act in a dual capacity. First, it is to house and preserve such samples of this furniture and artifacts as may be available as living evidence of the skill of the colony workman. Second, it is hoped that the presence of this building and its contents may stand as a symbol of the unique character of the colony and recall its early tradition and the heritage of the fruitful days of this peaceful, law-abiding, and music loving colony of Aurora.2

Barker continued to attend monthly meetings of the Society. Barker asked at the January meeting

1

Barker, Speech at dedication of Ox Barn Museum, 25 September 1966, A.C.H.S. Files.

2 Ibide 
...if it would be possible to change the meeting date from the third Thursday to the second Thursday as it conflicted with a meeting of his and also Mrs. Powers. After a lengthy discussion it was moved by: John Kraus $\mathrm{Jr}$. and seconded by Mr. Pursley that we retain the meeting date on the third Thursday but that meetings be held every month instead of every two months. Motion carried.1

Barker attended the February meeting where he

...spoke briefly and outlined the procedure that was necessary to try and get some financial help from county and the state highway commission to help maintain the museum.2

Marion County did distribute a few hundred dollars between the Aurora Colony Historical Society and the Marion County Historical Society for a couple of years.

Barker had been negotiating with historical society members Ernest and Marion Becke about donating the colony log cabin that Becke's grandfather George Steinbach built in 1876. This cabin was on the Becke's farm. Barker wanted to move it to the grounds of the museum, but Becke was using the building as a storage shed. Meanwhile. Barker was in the hospital and was in serious condition. In May 1967

Mrs. Sprouse reported...she was trying to get the old log cabin from Ernest Becke and have it moved to the back of the Ox Barn and connect it to a storage shed. She had contacted Wayne Van Lieu and he reported it could be moved. Mrs. Sprouse desired to know the wish of the members as to the procuring of the cabin. It was regularly moved and seconded that

\footnotetext{
1 files. "Minutes of the Meeting," 19 January 1967, A.C.H.S.

2 files. "Minutes of the Meeting," 17 Februany 1967, A.C.H.S.
} 
the membership back Mrs. Sprouse one hundred percent....1

By July Barker was out of the hospital and, along with his daughter, attended the meeting. "Mrs. Sprouse briefly spoke and said she was well pleased with the wagon shed...." Barker asked

...about trying to get all the three bells from the old Colony church as it was definitely something that belonged to the museum as a complete unit.... Barker also said to his knowledge the original log cabin to be moved to the museum would be the only original log cabin in 'captivity' as most cabins were only replicas.2

An agreement was made with the Beckes that Barker would finance the building of a new shed if they donated the log cabin. The cabin was then donated to the historical society.

The cabin was moved approximately five miles August 1 , 1967. Arthur Berg of Mt. Angel was the contractor who did the actual moving. "The width of the Mill creek bridge in Aurora was barely enough to allow the move, and the moving rig barely cleared the Aurora railroad crossing before train time." ${ }^{3}$ The same article also mentioned that Barker had files. "Minutes of the Merting," 18 May 1967, A.C.H.S.

1

2 files.

"Minutes of the Meeting," 20 July: 1967, A.C.H.S.

\section{3}

"Colonist Handwork Preserved," Canby Herald, 3 August 1967, A.C.H.S. files. 
been at the cabin several times. Barker called it "...the finest he has seen." 1

In November Barker was honored by the Men's Garden Club of Portland. Barker, a long time gardening enthusiast, was a member of the club. Unfortunately, Barker was unable to attend because he was in the hospital recovering from a bout with pneumonia. His daughter was there to represent $\mathrm{h} f \mathrm{~m}$ on November 29, 1967, when the club planted a twelve foot red oak tree in his honor on the grounds of the Museum. Clarence W. Walls, president of the club, said in his speech,

One day when I visited him in the hospital he told me that he was a little worried at one time during his early illness. He said he was sure that Mrs. Powers and Barbara could see this 0x Barn project through without him, but he did want to stay here long enough to see his final project, The

Parsonage' in Salem completely restored.2

In June 1968, it was announced that historical society member John Kraus, Sr, was giving the old Kraus home to the Society. "The President reported the board had met and thought it advisable to move the Kraus house on the present museum property." 3 The motion carried. The ground was

\section{1} "Colonis ts Handwork Preserved," Canby Herald, 3 August 1967, A.C.H.S. files.

2

Clarence W. Walls, Speech at dedication of tree to honor Barker, 29 Norember 1967. A.C.H.S. Piles.

3

"Minutes of the Meeting." 20 June 1968, A.C.H.S. 
leveled and the house was made ready to move. The money to move and restore the house was given by Barker and his daughter. At the September meeting,

Mrs. Sprouse led a discussion on restoration of the Kraus house. It is her idea that the house should be restored as closely to the original as possible. However instead of cedar posts for the foundation, it was decided to use cement blocks and skirt them with lumber. The furnishing will have to be decided on. It is planned to use some pieces from the Ox Barn Museum, and others will have to be acquired. There will be no crafts in the Kraus house. Lamps and 'candles' will be electrified. For heat it is planned to use portable heaters attached to base plugs. This will serve to keep the house dry and provide minimum heat. The walls are to be plastered and papered. A chimney is to be rebuilt.1

The heating system chosen was electric ceiling heat. The lighting used was flood lights in the ceiling, with dimmer switches. The living room and both bedrooms were wallpapered.

Barker died on January 29, 1969, in Portland. He did not live to see the dedication of the Parsonage, but he did live to see the Ox Barn Museum take shape much as it is today. The only difference has been the addition of a wash house, an outhouse, and an herb garden. The museum is largely self-sustaining due to the admission charge and the various fundraising activities including a quilt show, sausage dinner, and strawberry social. The society has been involved for several years restoring the Stauffer-Will farm

1 "Minutes of the Mereting," 19 September 1968, A.C.H.S. 
which was built in the late $1860^{\prime} \mathrm{s}$ two and one half miles south of Aurora. The society's project consists of a two and one half story $\log$ house and Colony barn set on two acres of land. This project has been financed by Mrs. Sprouse and grants from the federal government. 


\section{CHAPTER VII}

\section{SULQLARY ANU CUNCLUSIONS}

Barker's interest in preservation stemmed from a deep sense of patriotism and a devotion to enrich the cultural heritage of his native state. He was very independent and saw it as his duty to help preserve Oregon's early history. In an article which appeared in Marion County history.

Barker outlined some of his philosophy concerning preservation.

Take the McLoughlin House in Oregon City. No one knows whether or not the interior now is as it was originally. Personally I do not think that it is, but in the restoration one does the best job possible after gathering all the evidence. We are going through that process now in restoring the Hoover house in Newberg. There we moved completely one part and built it anew. All restoration does exactly that. Judging from what I know of the Parsonage it could be restored accurately. In Williamsburg many houses were completely rebuilt. Where they had the original plans they used them. but in many instances there is not an original brick used. That is known. That is restoration, and one is not discarding old houses because windows, doors, and stairs are gone or changed. Those who advocate that simply argue against almost any restoration.1

Barker's statement that in a "...restoration one does the best job possible after gathering all the evidence" sums

\section{1}

Barker, "The Parsonage, A Heritage," Marion County History, Vol. 1 (June 1955), 3 - 5 . 
up his approach to the various projects in which he became involved. His training in law proved to be very useful in his historical research and involvement in preservation. He always tried to find out as much as possible about the history of the building. This included the people who built it and why it was important and worth saving.

Barker's reference in Marion County History to Williamsburg and its approach to restoration helps to explain some of his actions. Colonial Williamsburg has long been the country's leading laboratory of historic preservation. Many people over the years having visited Williamsburg have gone home to emulate the kinds of things Williamsburg was doing. Decisions regarding furnishings, restorations, and living history have been repeated in many house museums throughout the country. Barker had been to Williamsburg and was influenced by the work there.

Barker was very concerned about Oregon losing its historic buildings. Having grown up in Oregon during its early years as a state, and knowing many of the pioneers, he gained an intense interest in the history of the area and a respect for the buildings left by these pople. Since he left Oregon for many years, he gained a respect that only one who has moved away from home and longs to return can have.

Barker continually argued that Oregonians did not fully appreciate the importance of preserving their history. 
In 1935. during the restoration of the McLoughlin home. Barker wrote to William M. Tugman, editor of the Eugene Register Guard and stated,

I am also interested in the matter because I feel that Oregon is liable to lose innocently through ignorance, many of her historical monuments if they are not soon cared for. Many of them are known only to a generation fast departing and if they are not located and marked in the near future they will be lost as historical monuments.... I do feel that Oregon is very slow and backward in recognizing and appreciating its own local history.1

Barker's preservation interests focused mainly on preserving buildings associated with the pioneers. Perhaps it was because they were the oldest and therefore the most rulnerable.

The field of historic preservation has changed drastically in the last fifteen to twenty years. The emphasis has changed from saving only those early buildings to what is now called "cultural resource management." Resource management calls for a much broader interpretation of what is important to save. Preservationists today are looking at buildings from all periods with an eye to trying to save examples from each period.

With the involvement of the state and federal government, and private preservation groups, the whole field has broadened drastically. Historic preservation has evolved to what Richard P. Matthews, director of the Washington County

1 Barker, Letter to William H. Tugman, 29 January 1935. M.M.A. Files。 
Museum calls,

... the greatest tax shelter since cattle ranches and oil wells.... It's no longer a handful of dogooders who are interested in preservation. Eusiness people, professional people, government and schools are saving what is left and demonstrating that it is cost effective.1

Barker may have disagreed with this new approach to historic preservation, but he most likely would not have opposed it. He intensely loved pioneer history and did all that he could to preserve it. With 80 much left to be done in this area he would have fought to see that the work was carried on. One of Barker's greatest assets was his ability to get other people interested. His enthusiasm was contagious among his friends. Included in this circle were many powerful and influential political, business, and community leaders. He always made it a point to let others know he appreciated their help and support. People who donated time or money would receive from him a very gracious thank you letter. Later he would follow this up with a letter keeping the donor advised on the progress of the project. Frequently, he would go directly to the person and talk with him. If Barker said he would do something, his friends knew that he meant it.

All of the preservation projects in which Barker was involved are still operating as historic sites open to the

1 Janet Goetze, "Victorian Night to Spotlight Effort at Preservation," Oreronian. 31 October 1981, B. 1, Col. 2. 
public. Many of these projects continue to benefit from Barker's original interest. His daughter Mrs. John Sprouse has been continuing the work of her father in tribute to him. She has served on the boards of several of the organizations and has contributed financially through a fund Barker set up for that purpose. The "dynasty" that Barker had hoped would continue this work does not seem to have passed on to his grandsons.

If it had not been for people like Barker, the pioneer history of Oregon would not be as well preserved as it is today. He was an interesting and generous individual. His involvement in preservation in Oregon was a role that he thoroughly enjoyed. Oregon is much richer today for having had Burt Brown Barker as one of its supporters. 
SOURCES CONSULTEU

SECONUARY WURKS

Books

Barker, Burt Brown. Minthorn House. Boyhood Home of Herbert Hoover. Newberg, Oregon: n.p., c. 1955.

-..-.-.. Autobiegraphy of Burt Brown Barker. Portland, Oregon: unpublished, 1905.

Bogue, Lucille. Colony House in Aurora. n.p.. 1965.

Clark, Malcolm, Jr. Pharisee Among Philistines, The Diary of Judge Matthew P. Deady 1871 - 1892. Portland, Oregon: Oregon Historical Society, 1975.

Dictionary of National Biography, From the Beginnings to 1900. London: 0xford University Press, 1961.

Hendricks, Robert J. Bethel and Aurora. New York: Press of the Pioneers, 1933.

Hoover, Herbert C. The Memoirs of Herbert Hoover, V.I. Years of Adventure $1874-1920$. New York : Macmilian Co., 1951.

Hosmer, Charles B., Jr. Presence of the Past. New York: G.P. Putnam's Sons, 1965.

-.----. Preservation Comes of Age. From Williamsburg to the National Prust. 1926 - 1949.2 Vols. Charlottesville: University Press of Virginia, 1981.

Johansen, Dorothy. Empire of the Columbia. 2nd edition. New York, Harper and Row, 1967.

Nordhoff, Charles. The Communistic Societies of the United States: From Personal Observations. New York : Dover Publications, Inc.. 1966. reprint from 1875 ed., New York: Harper \& Brothers.

0lsen, Deborah M. Minthorn house. Boynood Home of Her bert c. Hoover. Newberg, Oregon: n.p., 1979. 
Research material, Minthorn House files,

Newberg, Oregon, 1979.

Smith, Gene. The Shattered Dream. New York: William Morrow \& Co... Inc., 1970.

Walton, Elisabeth. "Mill Place on the Willamette, A New Mission house for the Methodists in Oregon, 1841 1844." M.A. Thesis, University of Delaware, 1965.

Weibe, Robert H. The Search for Order, $1827-1920$. New York: Hill \& Wang, 1968.

\section{Articles}

Barker, Burt Brown. "The Parsonage: A Heritage." Marion County History. Vol. $1,(1955)$, pp. $3-5$.

Cayfield, Louis R. "The Exploratory Excavation of Fort Clatsop." Oregon Historical Quarterly. Vol. XIIX, No. 3, $(1948)$, pp. $205-210$.

Mission Mill Museum Newletter, End of Summer 1972, Mission Mill Museum files, Salem, Oregon.

"Notes." Oregon Historical Quarterly. Vol. II, No. 3, September 1950, p. 228.

Ross, Marion D. "Architecture in Oregon, 1845 - 1895." Oregon Historical Quarterly, IVII, No. 1, (Narch 1956), pp. 33 - 64 .

\section{PRIMIARY SOURCES}

\section{Manuscripts}

Barker, Burt Brown. Unpublished correspondence, notes, minutes, and scrapbooks: Minthorn House files, Newberg, Oregon. Mission Mill Museum files, Salem, Oregon. Ox Barn Museum files, Aurora, Oregon. McLoughlin House files, Oregon City, Oregon. W.P.A. files, State Iibrary, Salem, Oregon.

-...-... Transcripts of Interviews. Oregon Historical Soiety, Portland, Oregon, 1962. 
Oregon Historical Society.

Brown, Chandler P. Mss. 1629.

Fort Clatsop National Memorial Papers. Mss. 212.

Stanton, Glenn A. Mss. 1040.

Tobie, Harvey E. Mss. 360 .

Potter, Elisabeth Walton. "Chronology." Author's file on Mission Mill Museum Association.

"Historic Preservation in Oregon." Oregon

State Highway Division, April, 1971, 1st ed., pp. 1 7 .

Newspapers

"A Bit of Early Day Precaution." n.p., 16 April 1939. 0.H.S.. Verticle file, Yamhill County.

"A Solution For The Lee Houses." Editorial. Capital Jour= nal, 18 February 1963.

Bowen, Aaron E. "Shameful Thing." Statesman, 8 February 1963. p. 4. Mission Mill Museum files, Salem, Oregon.

"Colonists Handwork Preserved." Canby Herald, 3 kugust

1967. Ox Barn Museum files, Aurora, Oregon.

"Early Salem Houses." Editorial. Statesman, 11 February 1963. Mission Mill Museum files, Salem, Oregon.

Editorial. Oregon City Enterorise. 9 August 1934, McLoughlin House files, Oregon City, Oregon.

"Fort Clatsop Triumph." Editorial. Oregonian, 25 May 1958. Mss. 212, 0.H.S., Portland, Oregon.

Goetze, Janet, "Victorian Night to Spotlight Effort at Preservation." Oregonian. 31 October 1981, B 1, Col. 2.

Harney, Elizabeth. "Hoover Boyhood Home Ownership to Change." Oregonian. 8 Uctober 1981, Sec. B, p. 2, cols. 1 - 2 .

"Historical Center Now Likely." Editorial. Captial Journal. 31 August 1963.

"Honoring His Memory." Oregon City Enterorise, 25 June 1909. McIoughlin House files, Uregon City, Oregon. 
Hughes, Harold. "Newberg's Surprise for Herbert Hoover." Oregonian. 7 August 1955, Minthorn House files, Newberg, Oregon.

"Jason Lee House Location Suggested." Capital Journal, 27 August 1963. Mission Mill Museum files, Salem, Oregon.

Jones, Alfred C. n.p., Ox Barn Museum files, Aurora, Oregon.

McArthur, Scott. "Jason Lee Museum Planned." Capital Journal, 22 February 1961, Mission Mill Museum files, Salem, Oregon.

McKay, Floyd. "Council Will Decide Fate of Weatherbeaten 123-year old Jason Lee House." Statesman, 17 February 1963. Mission Mill Museum files, Salem, Oregon.

McKinney, Lewis. "Pictures Not Houses." Statesman, 10 February 1963. Mission Mill Museum files, Salem, Oregon.

"McLoughlin Home May be Demolished." Oregon City Enterprise, 2 April 1909. McLoughlin House files, Uregon City, Oregon.

"McLoughlin Home Saved." Oregon City Enterprise, 24 April 1908, McLoughlin House files, Uregon City, Oregon.

"McLoughlin Home Stays." Oregon City Enterprise, 18 December 1908, Mcloughlin House files, Oregon City, Oregon.

"McLoughlin House." Oregon City Enterprise, n.d., McLoughin House files, Oregon City, Oregon.

"McLoughlin is Honored." Oregon City Enterprise, 10 September 1909, McLoughlin House files, Oregon City, Oregon.

Mershon, Helen I. "Here's House That Faith Built." Oregon Journal, 23 April 1963. Mission Mill Museum files, Salem, Oregon.

Morrison, Allen. "Junking of Jason Lee House Called for by Alderman Meeks." Statesman, 29 September 1964, p. 5 .

"Old Parsonage To Be Restored." Capjtal Journal, 23 February 1966, Mission Mill Museum files, Salem, Oregon.

"Work of Improving M'Loughlin House Will Start Today." Oregon City Enterveise, 15 February 1935. McLoughlin House files, Oregon City, Oregon. 


\section{PiIm}

To Your Health. With Burt Brown Barker. T.V. broadcast by KGW-AM/FM. McLoughlin House files, Oregon City, Oregon.

\section{Oral Interview}

Duniway, David. Telephone interview. 27 October 1981. 